Provided for non-commercial research and education use. Not for reproduction, distribution or commercial use.

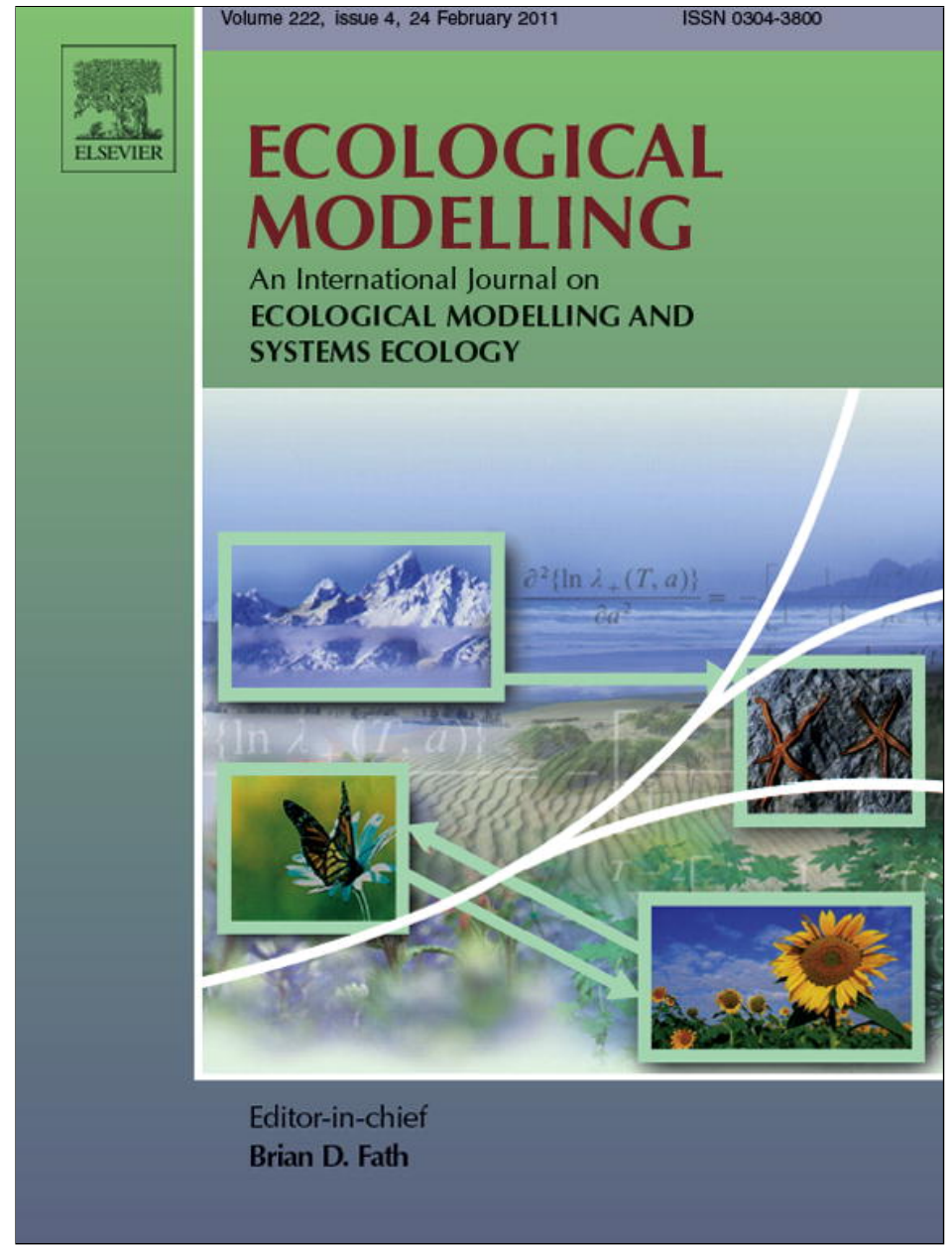

This article appeared in a journal published by Elsevier. The attached copy is furnished to the author for internal non-commercial research and education use, including for instruction at the authors institution and sharing with colleagues.

Other uses, including reproduction and distribution, or selling or licensing copies, or posting to personal, institutional or third party websites are prohibited.

In most cases authors are permitted to post their version of the article (e.g. in Word or Tex form) to their personal website or institutional repository. Authors requiring further information regarding Elsevier's archiving and manuscript policies are encouraged to visit:

http://www.elsevier.com/copyright 
Review

\title{
Modelling natural disturbances in forest ecosystems: a review
}

\author{
Rupert Seidl $^{\mathrm{a}, \mathrm{b}, *}$, Paulo M. Fernandes ${ }^{\mathrm{c}, \mathrm{d}}$, Teresa F. Fonseca ${ }^{\mathrm{d}}$, François Gillet ${ }^{\mathrm{e}, \mathrm{f}}$, Anna Maria Jönsson ${ }^{\mathrm{g}}$, \\ Katarína Merganičová ${ }^{\mathrm{h}, \mathrm{i}}$, Sigrid Netherer ${ }^{\mathrm{j}}$, Alexander Arpaci $^{\mathrm{a}}$, Jean-Daniel Bontemps ${ }^{\mathrm{k}}$, \\ Harald Bugmann ${ }^{1}$, Jose Ramon González-Olabarria ${ }^{\mathrm{m}}$, Petra Lasch $^{\mathrm{n}}$, Céline Meredieu ${ }^{\mathrm{o}}$, \\ Francisco Moreira $^{\mathrm{p}}$, Mart-Jan Schelhaas ${ }^{\mathrm{q}}$, Frits Mohren ${ }^{\mathrm{r}}$
}

a Institute of Silviculture, Department of Forest and Soil Sciences, University of Natural Resources and Applied Life Sciences (BOKU) Vienna, Peter Jordan Straße 82, 1190 Wien, Austria ${ }^{\mathrm{b}}$ Department of Forest Ecosystems and Society, College of Forestry, Oregon State University, 3200 SW Jefferson Way, Corvallis, OR 97331, USA

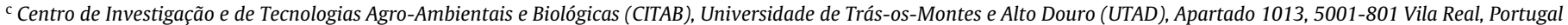

${ }^{\mathrm{d}}$ Department of Forest and Landscape, Universidade de Trás-os-Montes e Alto Douro, Apartado 1013, 5001-801 Vila Real, Portugal

e Université de Franche-Comté CNRS, UMR 6249 Chrono-Environnement, 16 route de Gray, 25030 Besançon Cedex, France

f École Polytechnique Fédérale de Lausanne, Laboratory of Ecological Systems, Station 2, 1015 Lausanne, Switzerland

${ }^{g}$ Department of Earth and Ecosystem Sciences, Division of Physical Geography and Ecosystem Analysis, Lund University, Sölvegatan 12, SE-223 62 Lund, Sweden

${ }^{\mathrm{h}}$ Czech University of Life Sciences in Prague, Faculty of Forestry, Wildlife and Wood Sciences, Department of Forest Management, Kamýcká 129,

16521 Praha 6, Suchdol, Czech Republic

${ }^{i}$ Forest Research, Inventory and Monitoring (FORIM), Huta 14, 96234 Železná Breznica, Slovakia

${ }^{\mathrm{j}}$ Institute of Forest Entomology, Forest Pathology and Forest Protection, Department of Forest and Soil Sciences, University of Natural Resources and

Applied Life Sciences (BOKU) Vienna, Hasenauerstraße 38, 1190 Wien, Austria

k AgroParisTech, ENGREF, UMR 1092 INRA/AgroParisTech “Laboratoire d'Etude des Ressources Forêt-Bois" (LERFoB), 14 rue Girardet, 54000 Nancy, France

${ }^{1}$ Forest Ecology, Institute of Terrestrial Ecosystems, Department of Environmental Sciences, Swiss Federal Institute of Technology ETH, Universitätstr. 22, CH-8092 Zurich, Switzerland

${ }^{m}$ CTFC - Forest Technology Centre of Catalonia, Carretera de Sant Llorenç de Morunys, km 2, 25280 Solsona, Spain

n Potsdam Institute for Climate Impact Research, RD II: Climate Impacts and Vulnerabilities, Telegrafenberg, P.0. Box 601203, 14412 Potsdam, Germany

o INRA, UMR1202 BIOGECO, 69 Route d'Arcachon, F-33610 Cestas, France

p Centre of Applied Ecology 'Prof. Baeta Neves', Institute of Agronomy, Technical University of Lisbon, Tapada da Ajuda, 1349-017 Lisbon, Portugal

${ }^{\mathrm{q}}$ Alterra, Wageningen University and Research Centre, Wageningen, The Netherlands

${ }^{\mathrm{r}}$ Forest Ecology and Forest Management Group (FEM), Wageningen University, P.O. Box 47, NL-6700 AA Wageningen, The Netherlands

\section{A R T I C L E I N F O}

Article history:

Received 21 February 2010

Received in revised form

28 September 2010

Accepted 28 September 2010

Available online 26 October 2010

\section{Keywords:}

Disturbance modelling

Wildfire

Wind storm

Drought

Insect herbivory

Browsing

\begin{abstract}
A B S T R A C T
Natural disturbances play a key role in ecosystem dynamics and are important factors for sustainable forest ecosystem management. Quantitative models are frequently employed to tackle the complexities associated with disturbance processes. Here we review the wide variety of approaches to modelling natural disturbances in forest ecosystems, addressing the full spectrum of disturbance modelling from single events to integrated disturbance regimes. We applied a general, process-based framework founded in disturbance ecology to analyze modelling approaches for drought, wind, forest fires, insect pests and ungulate browsing. Modelling approaches were reviewed by disturbance agent and mechanism, and a set of general disturbance modelling concepts was deduced. We found that although the number of disturbance modelling approaches emerging over the last 15 years has increased strongly, statistical concepts for descriptive modelling are still largely prevalent over mechanistic concepts for explanatory and predictive applications. Yet, considering the increasing importance of disturbances for forest dynamics and ecosystem stewardship under anthropogenic climate change, the latter concepts are crucial tool for understanding and coping with change in forest ecosystems. Current challenges for disturbance modelling in forest ecosystems are thus (i) to overcome remaining limits in process understanding, (ii) to further a mechanistic foundation in disturbance modelling, (iii) to integrate multiple disturbance processes in dynamic ecosystem models for decision support in forest management, and (iv) to bring together scaling capabilities across several levels of organization with a representation of system complexity that captures the emergent behaviour of disturbance regimes.
\end{abstract}

(c) 2010 Elsevier B.V. All rights reserved.

* Corresponding author. Tel.: +43 15417588779.
E-mail address: rupert.seidl@boku.ac.at (R. Seidl). 


\section{Contents}

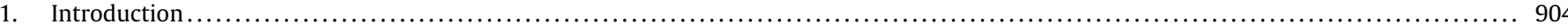

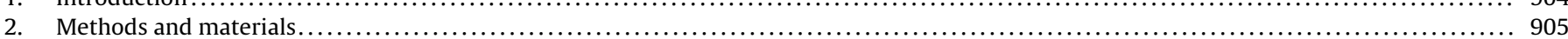

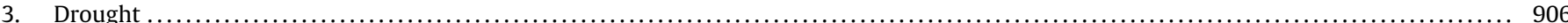

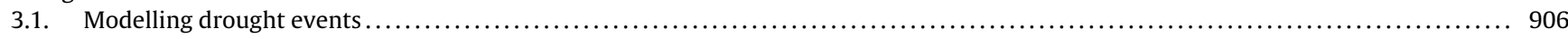

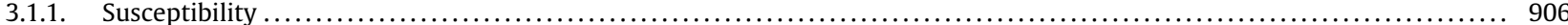

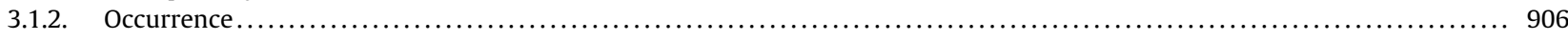

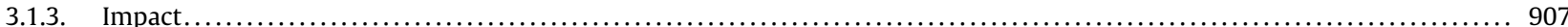

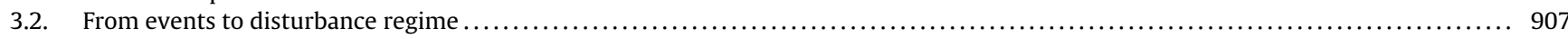

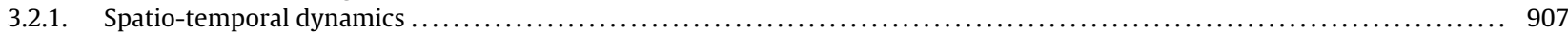

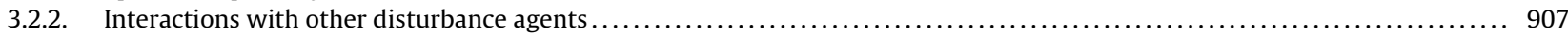

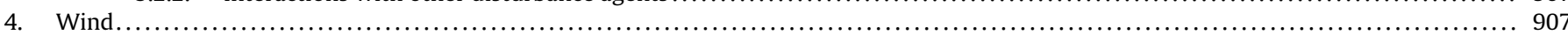

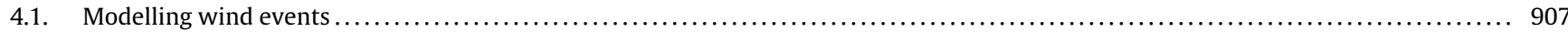

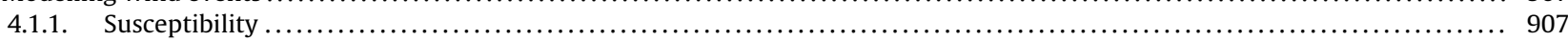

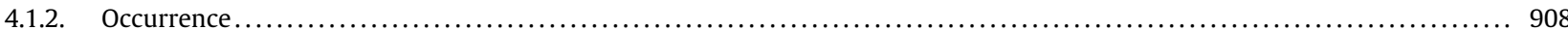

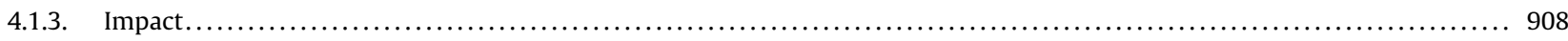

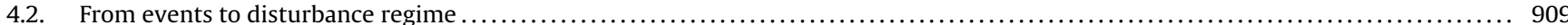

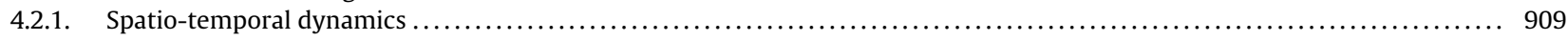

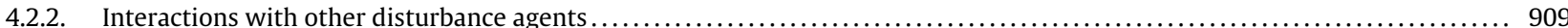

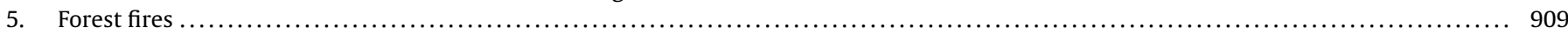

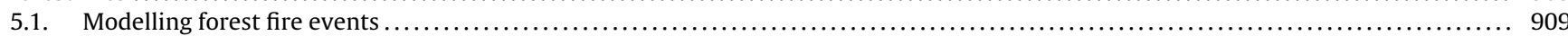

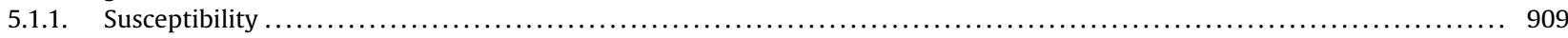

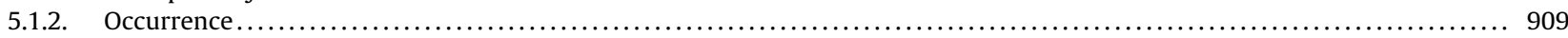

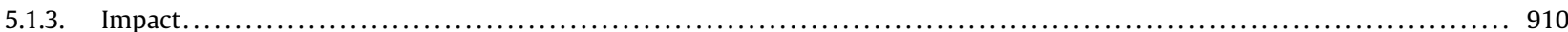

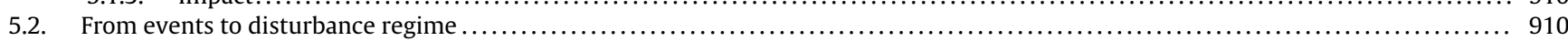

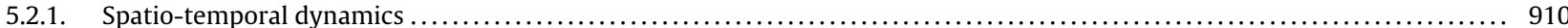

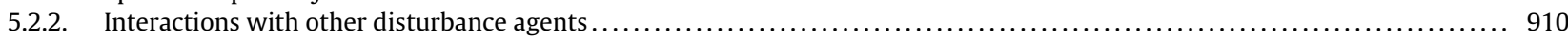

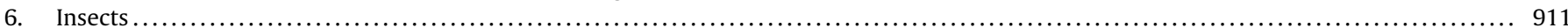

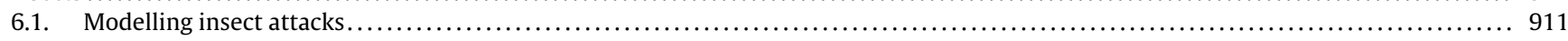

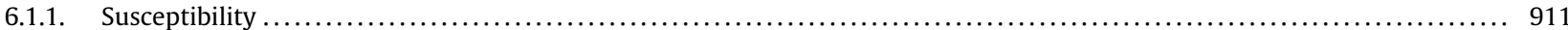

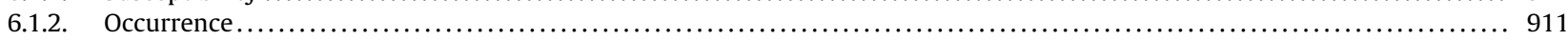

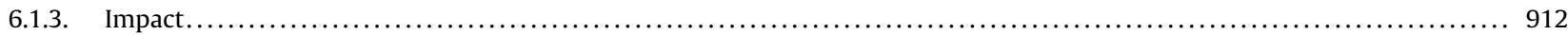

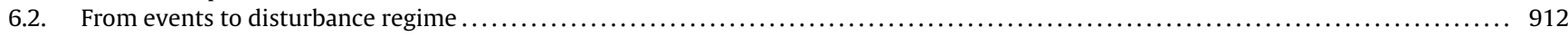

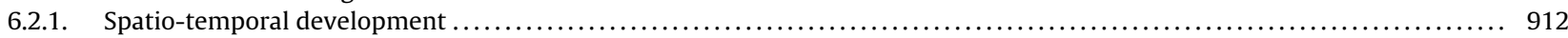

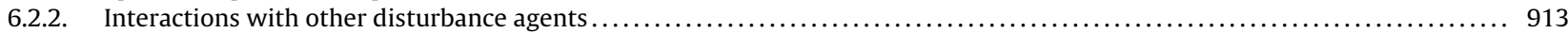

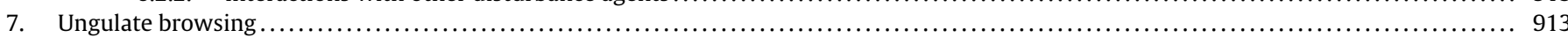

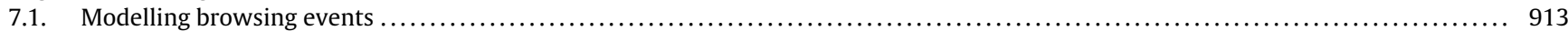

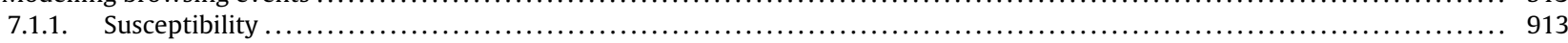

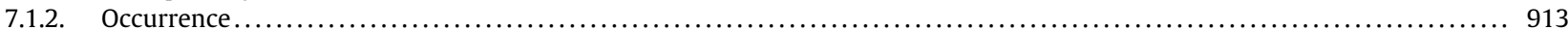

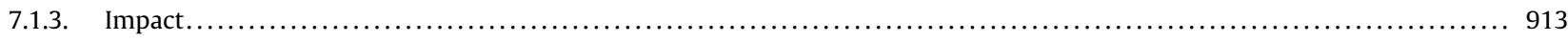

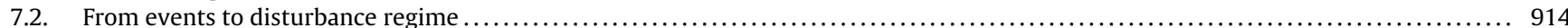

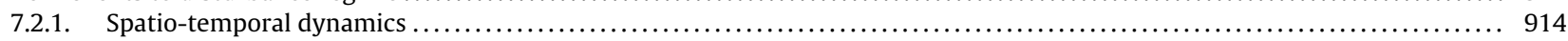

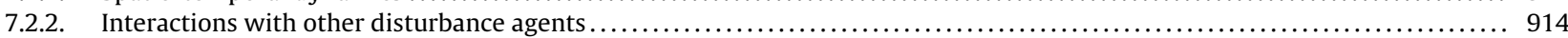

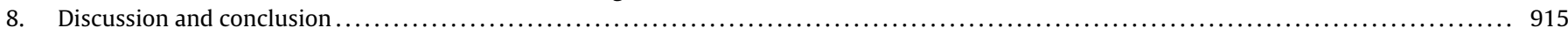

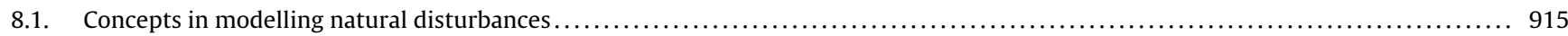

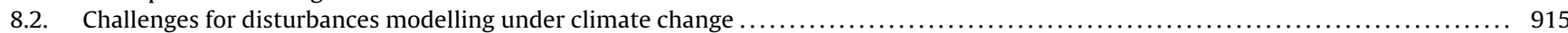

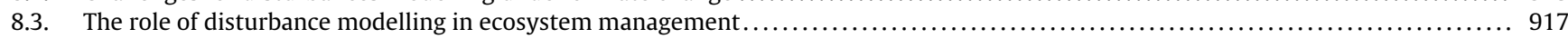

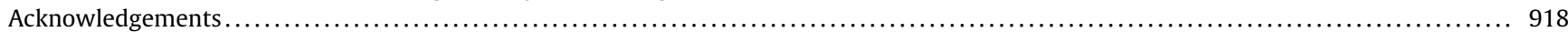

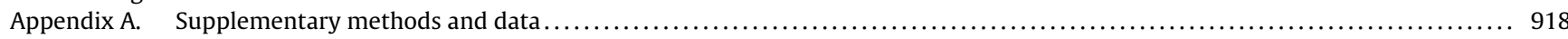

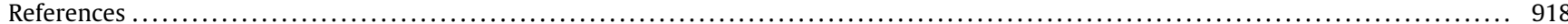

\section{Introduction}

Disturbances are key processes in forest ecosystem dynamics (Oliver and Larson, 1996). They strongly influence the structure, composition and functioning of forest ecosystems (Franklin et al., 2002) and determine the spatial and temporal patterns of forested landscapes (Forman, 1995). Analyses of old-growth forest ecosystems show that the temporal and spatial interplay between individual tree mortality and disturbances at varying scales, from small gaps to landscapes, is creating the multitude of successional pathways observed in natural forest ecosystems (Spies, 2009). Furthermore, disturbance processes are a key driver for evolutionary plant strategies (Grime, 2001; Gutschick and Bassirirad, 2003).

Due to their important role in forest dynamics, disturbances are relevant factors also in the management of ecosystems for functions, goods and services. Traditional management paradigms, originating in Central Europe in the 19th century and aiming at sustained timber yield, largely neglected disturbance dynamics in their conceptual design (cf. Puettmann et al., 2009), a fact that is also reflected in early modelling concepts such as yield tables (see Pretzsch et al., 2008 for a historical overview). Consequently, these management paradigms aimed at an exclusion or at least minimization of disturbance impacts, as these were viewed as interfering with "normal" forest structure and development. However, the recent disturbance history of managed forests in Europe and elsewhere clearly documents that these efforts widely failed (e.g., Schelhaas et al., 2003), and that disturbances such as wind storms and forest fires play a key role in the resource economy of most forested regions worldwide (e.g., Baur et al., 2003; Prestemon and Holmes, 2004).

With the increasing valuation of ecosystem services beyond timber production and a focus on the protection of biodiver- 
sity, a contrasting view of natural disturbances has been adopted in forest management. In the ecosystem management approach (Christensen et al., 1996; Kohm and Franklin, 1997), natural disturbances are recognized as blueprints for "close-to nature" management, assuming that the ecosystem and its components (e.g., endangered species) are resilient to disruptions that closely mimic natural dynamics (e.g., Palik et al., 2002; Bouchard et al., 2008). Emerging management frameworks such as the "historical range of variability" (Keane et al., 2009) explicitly address the important role of disturbances in ecosystem dynamics, but challenges remain with regard to their social acceptance and practical implementation (e.g., Wong and Iverson, 2004; Long, 2009).

In addition, climatic changes have the potential to rapidly invalidate historical baselines by altering key drivers of disturbance regimes (Lindner et al., 2010). For example, insects are affected directly by changes in temperature due to their ectothermic metabolism. Although numerous additional factors such as host availability and synchronization contribute to the complexity of climate-insect systems, climate change is expected to predominantly facilitate insect herbivores in temperate and boreal forest ecosystems (Bale et al., 2002; Battisti et al., 2005; Netherer and Schopf, 2010). Forest fires and large-scale drought events are further examples for disturbance events directly dependent on climate. Recent heat/drought episodes such as the European heat wave of 2003 (Rebetez et al., 2006) and the drought period in the south-western US (Breshears et al., 2005) have had strong impacts on forests (van Mantgem et al., 2009; Allen et al., 2010), and are likely to occur more frequently in the coming decades. Also, recently observed increases in fire frequency and severity have been linked to changes in the climate system (Westerling et al., 2006).

Quantitative models are powerful tools to analyze the complex relations between disturbances and their environment as well as their interactions with forest management by formalizing our understanding and allowing quantitative hypothesis testing. Considering the complexity of forest ecosystem dynamics, models are particularly useful (i) for a structured scientific analysis and quantitative evaluation of our understanding, and (ii) for harnessing scientific knowledge towards sound ecosystem management (cf. Bunnell and Boyland, 2003). Concurrent with an increasing ecological understanding considerable advances in the modelling of natural disturbance processes have been made over the last decades (e.g., Ryan, 2002; Keane et al., 2003, 2004 for fire; Gardiner et al., 2008 for windthrow, Malmström and Raffa, 2000; Dukes et al., 2009 for insect herbivory). Yet, despite increasing knowledge on individual processes and their modelling, this potential has had only limited impact on forest ecosystem modelling (Johnson and Miyanishi, 2007), such that a coarse representation of disturbance regimes persists in these models (Cushman et al., 2007). As a consequence, disturbances are still widely neglected in models that are applied in a forest management context, potentially leading to biased results in model-based decision support (Seidl et al., 2008), or disturbance regimes are imposed on models by external parameters rather than being simulated as emergent properties of system dynamics (cf. Schumacher and Bugmann, 2006).

To facilitate future efforts in disturbance modelling in this regard, our objective was to provide a review of the different approaches to modelling natural disturbances, addressing the full range of disturbance processes from individual events to integrated disturbance regimes. Based on the notion that disturbances are frequently interacting, we review a variety of disturbance agents rather than restricting our view to a single agent. To consistently analyze modelling concepts across agents we apply a common, process-oriented framework founded in disturbance ecology. Our specific objectives were (i) to review the wide variety of disturbance modelling approaches for different disturbance agents, and (ii) to synthesize modelling concepts and highlight challenges with regard to an improved integration of disturbances in dynamic ecosystem models in the context of forest management and climate change.

\section{Methods and materials}

We adopted a definition of disturbance that is rooted in forest ecosystem dynamics, where it is a discrete event in time that disrupts ecosystem structure, composition and/or processes by altering its physical environment and/or resources, causing destruction of plant biomass (synthesized from White and Pickett, 1985; Gunderson, 2000; Grime, 2001; White and Jentsch, 2001). Factors characterizing disturbances such as their abruptness, duration and magnitude are considered relative to ecosystem properties and their characteristic time scales. "Discrete" thus implies that a disturbance does not necessarily occur instantaneously, but rapidly relative to the change in the system's state variables that would occur in the absence of disturbance. We restricted our review to natural disturbances and focused on disturbances that do not irreversibly alter system integrity, i.e. processes within the domain of general systems stability (cf. Gunderson, 2000).

We structured our review according to disturbance agents, addressing drought, wind, fire, insect pests and ungulate browsing (Sections 3-7). Addressing this diverse set of abiotic and biotic disturbance agents we aimed at covering the broad range of scales and processes relevant for the modelling of complex, integrated disturbance regimes. To facilitate a process-oriented view we further structured the review according to main disturbance mechanisms. We followed White and Jentsch (2001) in distinguishing the modelling of an individual disturbance event vs. the larger context of a disturbance regime (cf. also Moloney and Levin, 1996). In compliance with White and Picketts' (1985) concept of disturbance analysis we reviewed models according to the five broad mechanisms susceptibility, occurrence, impact, spatio-temporal

Table 1

The process-oriented structure for reviewing disturbance modelling approaches in this study, and its relation to commonly used disturbance descriptors.

\begin{tabular}{|c|c|c|c|}
\hline Level of organization & Mechanism & Aspects addressed in modelling & Related disturbance descriptors ${ }^{\mathrm{a}}$ \\
\hline \multirow[t]{3}{*}{ Disturbance event } & Susceptibility & $\begin{array}{l}\text { Predisposition of forest vegetation (i.e., lack of } \\
\text { resistance to agent) }\end{array}$ & Frequency, return interval, predictability \\
\hline & Occurrence & $\begin{array}{l}\text { Sensitivity of disturbance agent to its environment } \\
\text { (e.g., climate, antagonists), triggering elements, } \\
\text { population levels }\end{array}$ & Frequency, return interval, predictability \\
\hline & Impact & $\begin{array}{l}\text { Effects on vegetation structure, composition and } \\
\text { functioning and their local spatial distribution }\end{array}$ & Magnitude, intensity, severity \\
\hline \multirow[t]{2}{*}{ Disturbance regime } & Spatio-temporal dynamics & $\begin{array}{l}\text { Spatial spread at landscape scale, correlation and } \\
\text { feedbacks with landscape patterns }\end{array}$ & Distribution \\
\hline & Interactions & $\begin{array}{l}\text { Facilitation (and competition) between } \\
\text { disturbance agents }\end{array}$ & Synergism \\
\hline
\end{tabular}

a Sensu White and Pickett (1985, p. 7). 


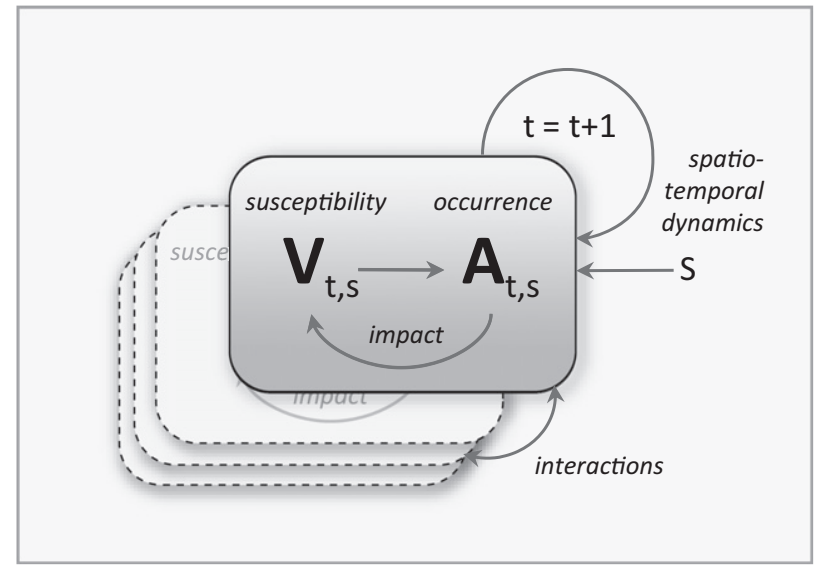

Fig. 1. A generic process-oriented framework for modelling natural disturbances in forest ecosystems. For a characterization of the five major disturbance processes (in italics) see Table 1 . The inner rounded box delineates a single disturbance event for a respective agent (at time $t$ and location $s$ ). The outer box contains the elements of the disturbance regime of a landscape $S$, i.e. spatial and temporal dynamics (e.g. the influence of adjacency and landscape context on a disturbance event (with $s \in S$ ), the temporal changes of susceptibility with succession) as well as interactions with other disturbance agents of the disturbance regime. $V=$ forest vegetation, $A=$ focal disturbance agent, $s=$ spatial location, $t=$ units of time.

dynamics and interactions (Table 1), resulting in a conceptual framework for disturbance modelling (Fig. 1) as the structural backbone of our analysis. Within this mechanistic framework we reviewed modelling approaches according to their process resolution and system dynamics, and synthesized general disturbance modelling concepts (Section 8). Since the utility of a model can only be judged in the context of its intended domain of application and a particular scientific question being asked, we largely refrain from a general valuation of approaches (sensu "model $\mathrm{x}$ is better than model y") in Sections 3 though 7, but we close with a discussion of current challenges and promising approaches for modelling natural disturbances in the context of climate change and forest management (Section 8).

The literature search was conducted using the databases of Elsevier Scopus ${ }^{\odot}$, ISI Web of Knowledge ${ }^{\odot}$, OvidSP $^{\odot}$, CAB Abstract $^{\odot}$, and Google Scholar ${ }^{\odot}$ during a six-month period from August 2009 to January 2010. Queries contained different permutations of the five selected disturbance agents (including aliases and explicit species names) and the mechanisms described in Table 1 as search terms. Additionally, we performed relational database searches exploiting the network of citations (forward and backward) around relevant disturbance modelling literature. In total 324 references to models and applications of disturbance modelling were included in our review (see Online Supplement).

\section{Drought}

\subsection{Modelling drought events}

\subsubsection{Susceptibility}

Water limitation affects forests at multiple levels (Breda et al., 2006); thus it is explicitly included in most forest ecosystem models. Still, we find an inclusion in our disturbance-focused review valuable since drought is an important factor in the interaction with other disturbance agents in forest ecosystems (e.g., Bigler et al., 2005) and the simulation of drought conditions remains challenging for current ecosystem modelling approaches (Hanson et al., 2004). In line with the scope of this review we focus on models addressing distinct drought periods leading to tree mortality (see McDowell et al., 2008 for a recent review of ecological mech- anisms), whereas gradual effects of water stress on processes such as growth are not the focus here.

Susceptibility of forest ecosystems to drought is mainly determined by site (e.g., soil texture, soil depth, water holding capacity) and stand (e.g., leaf area, species composition, rooting depth) characteristics. In models explicitly simulating water cycling in forest ecosystems, site conditions are represented at varying levels of detail, including one- or multi-layered soils as well as different schemes of water extraction based on soil texture (see Wullschleger et al., 2001; Hanson et al., 2004; Grant et al., 2006 for an overview over different concepts). In most models these characteristics strongly shape the predisposition of a site to a drought event, yet the scarce availability of detailed soil data for model parameterization and initialization often limits the applicability of a complex soil representation in landscape-scale simulations. Many widely applied physiological models (i.e. approaches that explicitly incorporate fundamental processes of tree physiology such as photosynthesis, respiration and allocation) and forest gap models (i.e. models simulating the forest as a composite of small patches of (potentially) different composition and successional stage) thus employ an onelayer bucket model (i.e. models assuming a single well-mixed body of water for a stand) specified by field capacity to permanent wilting point (e.g., Bugmann and Solomon, 2000: FORCLIM; Thornton et al., 2002: BIOME-BGC). Examples for process-models utilizing a more complex soil architecture are given by Grote and Pretzsch (2002: BALANCE) and Lasch et al. (2005: 4C).

In physiological models including a detailed routine to calculate transpiration, trees consume water from the soil storage $\operatorname{pool}(\mathrm{s})$, thus accounting for soil-vegetation-atmosphere feedbacks. Increasing drought susceptibility due to higher stand-level water demand is an emerging property of such approaches (e.g., Running and Coughlan, 1988: FOREST-BGC; Sitch et al., 2003: LPJ). Hanson et al. (2004) in their analysis of 13 detailed process models (hourly to monthly time-step) found that also the conductance gradient within a canopy is important in "big leaf" approaches (i.e. models with a linear scaling of leaf photosynthesis processes to canopies, stands and landscapes) to accurately simulate the water cycle. Further interactions between stand structure and water availability are included in models that simulate the interception of precipitation.

In many gap models, which are explicitly designed to simulate species dynamics, species-specific drought tolerance is considered mostly by means of an ordinal ranking with regard to a drought response scalar (cf. Bugmann and Cramer, 1998: FORCLIM; Wullschleger et al., 2001), rather than a consideration of physiological mechanisms and responses. More detailed approaches consider the species-specific distribution of fine root surface area in different soil layers in the competition for water among individual trees (e.g., Grote and Pretzsch, 2002). In addition to site and stand characteristics directly influencing the water balance, other stressors can influence the predisposition of trees to drought. In many gap models the occurrence of multiple stressors additionally predisposes trees to die in case of drought, due to lowered margins to mortality thresholds (Keane et al., 2001).

\subsubsection{Occurrence}

The explicit simulation of the onset of drought requires information on the course of climate drivers and the resulting soil water dynamics at daily or smaller time steps (Tiktak and van Grinsven, 1995), although some models also operate on a monthly basis (Nepstadt et al., 2004: RisQue), or even at annual time steps (van Minnen et al., 1995: FORSOL). In process models, the driving force is plant available soil water (Tiktak and van Grinsven, 1995; Nepstadt et al., 2004). Drought stress occurs if the actual plant-available soil water falls below a certain predefined threshold value, e.g., below the wilting point (van Minnen et al., 1995). For example, in the process model $4 \mathrm{C}$ drought stress occurs if the 
daily water demand depending on potential evapotranspiration, interception evaporation and unstressed stomatal conductance of the forest stand exceeds the water supply from the soil (Lasch et al., 2005). Detailed physiological models explicitly simulate thresholds in leaf water potential, with some approaches also accounting for sapwood water storage as well as root and xylem conductivity (e.g., Martinez-Vilalta et al., 2002; Zavala and Bravo de la Parra, 2005). Process models capturing the gradual onset of drought periods with fine temporal resolution (i.e., hourly) frequently contain formulations balancing water supply and demand of the soil-root-canopy system (cf. Grant et al., 2006).

In another model family drought stress has been related to the ratio of vegetation demand (potential evapotranspiration, PET) vs. supply of water from the soil (actual evapotranspiration, AET), in relation to species-specific thresholds (e.g., Prentice et al., 1993: FORSKA; Bugmann, 1996: FORCLIM; Lexer and Hönninger, 2001: PICUS). The number of drought days has also been proposed as proxy for drought disturbance and mortality in simulation models (e.g., van Minnen et al., 1995), but has been found inferior compared to the AET approaches described above (cf. Fischlin et al., 1995: FORCLIM).

In contrast, the water cycle is not simulated explicitly in empirical models. For example, simple regression approaches based on climate drivers have been used to estimate drought occurrence and impact (Solberg, 2004). In empirical simulation models, the occurrence of drought stress can be included probabilistically via empirically derived distributions of prior drought events for a specific region. A modification of such historical data allows for scenario analysis also in empirical simulators (e.g., Fabrika and Vaculčiak, 2009: SIBYLA).

\subsubsection{Impact}

Although a number of physiological models simulate the circumstances leading to drought at a very detailed level, the modelled ecosystem impact typically focuses on short-term gas exchange and the resulting growth reduction (e.g., Hanson et al., 2004). While the drought-related decline of ecosystem pools is accounted for in such approaches, drought disturbances and the resulting pulses of tree mortality are not simulated explicitly. In this regard Zavala and Bravo de la Parra (2005) presented a process-based individual tree model that explicitly accounts for water stress and subsequent drought-induced tree mortality, using days with leaf water potential approaching the cavitation threshold as the key driver. Martinez-Vilalta et al. (2002) used hydraulic loss in xylem conductivity and its feedback to leaf area as a proxy for the death from drought in their detailed plant water transport model. GOTILWA+ (Sabate et al., 2002), which simulates drought-induced mortality through a water-deficit mediated negative carbon balance, additionally includes a drought-related response of foliage phenology tailored to Mediterranean conditions. It is thus able to simulate the immediate plant response to a drought disturbance in terms of leaf area loss, rather than assuming full elasticity (i.e. an immediate recovery of foliage after the drought event). A delayed recovery from drought is also incorporated in the process-based model CABALA (Battaglia et al., 2004), where trees have a memory of plant water stress that reduces stomatal conductance for a certain period after the stress is removed.

In contrast to many physiological approaches, models of long-term ecosystem dynamics generally simulate tree mortality directly (Keane et al., 2001). Albeit at a coarser process resolution (but see, e.g., Friend et al., 1997: HYBRID), such models are able to simulate the effects of drought disturbances on ecosystem dynamics and succession. The effects range from a few individuals dying to a complete loss of living tree biomass in response to drought, accounting for the growth history of the affected individuals (Keane et al., 2001). However, most gap models assume full elasticity, i.e. if the drought duration is shorter than the stress threshold no mortality occurs and no feedbacks to tree vitality are simulated. Furthermore, mortality thresholds and assumptions in such model formulations are frequently based on theoretical considerations scarcely corroborated with empirical data and difficult to parameterize. In this regard Bigler and Bugmann (2004) and Wunder et al. (2006) presented efforts to evaluate and improve such theoretical mortality models with empirical data. However, one problem in this context is that empirical models tend to be site- and time-dependent (cf. Wunder et al., 2008). Considering these complexities and uncertainties, McMahon et al. (2009) used a hierarchical modelling framework applying a Bayesian approach to embrace such aspects in model predictions of drought disturbance.

\subsection{From events to disturbance regime}

\subsubsection{Spatio-temporal dynamics}

Spatio-temporal dynamics of drought regimes are modelled mainly with regard to the spatial distribution of predisposing soil characteristics in combination with spatial and temporal variation in climate drivers (e.g., precipitation, temperature, vapour pressure deficit, radiation). Spatial patterns and trajectories over time are thus mostly determined by abiotic drivers, and are not primarily an emerging property of the model itself. However, subsurface water flow and thus local water availability are strongly influenced by topography, particularly in landscapes characterized by complex (i.e., mountainous) terrain. Such topographic effects on hydrology, influencing spatio-temporal dynamics of drought regimes, can be modelled implicitly (i.e. statistical partitioning of watersheds into hydrologically similar areas, e.g., the TOPMODEL approach of Beven and Kirkby, 1979) or explicitly (i.e. simulate lateral flow between entities, e.g., the DHSVM approach of Wigmosta et al., 1994). Band et al. (1993: RHESSys) and Engel et al. (2002) give examples for an integration of the former approach within established physiological modelling frameworks that can be used to study spatio-temporal landscape level drought patterns. Integrated ecosystem models using explicit soil water routing are still scarce, although the work by Tague and Band (2001: RHESSys) highlights the advantage of this approach in simulating spatially distributed soil moisture patterns.

\subsubsection{Interactions with other disturbance agents}

Drought is an important predisposing factor for a number of other disturbance agents, and these interactions are thus modelled in a variety of approaches, particularly with regard to fire and insect herbivory (cf. Sections 5 and 6). However, the influence of other disturbance agents on drought-induced mortality (addressed here) is limited, and mostly restricted to a reduction in competition for available water via mortality. Such interactions can be modelled by all above-mentioned process-based approaches that include disturbance feedbacks on vegetation structure and water cycling.

\section{Wind}

\subsection{Modelling wind events}

\subsubsection{Susceptibility}

The susceptibility of forest ecosystems to wind damage is determined by tree and stand characteristics (e.g., tree species, tree/stand height, slenderness of trees, crown and rooting characteristics, stand density) as well as site characteristics (soil type, soil moisture content, topography). Essentially, all these factors need to be accounted for in modelling susceptibility to windthrow and/or wind breakage. Early conceptual models based on qualitative assessments were proposed for this task (e.g., Tang et al., 1997; Mitchell, 1998). Penalty point-based predisposition rating systems 
were employed to combine stand and site predisposition factors in expert systems (Führer and Nopp, 2001). Non-parametric quantitative models such as classification and regression trees or gradient boosting were recently harnessed to model windthrow susceptibility (e.g., Dobbertin, 2002; Lindemann and Baker, 2002; Kupfer et al., 2008).

However, by far the most common empirical approach to develop windthrow models based on stand and site characteristics is logistic regression, using site variables (e.g., Kramer et al., 2001), site and stand variables (e.g., Lohmander and Helles, 1987; Jalkanen and Mattila, 2000; Mitchell et al., 2001), individual tree variables (e.g., Peterson, 2004; Rich et al., 2007) or combinations of these (e.g., Valinger and Fridman, 1999; Fonseca, 2004: ModisPinaster; Mayer et al., 2005) as predictors. Spatial and neighbourhood aspects were also included as explanatory variables in such statistical approaches (e.g., Scott and Mitchell, 2005; Schindler et al., 2009). While most of these studies generally achieved satisfactory explanatory power, a high level of stochasticity was documented, e.g., in the analysis by Schütz et al. (2006). Considering the incomplete and "noisy" data sets common to disturbance modelling, methods from artificial intelligence recently proved to be superior to logistic regression in modelling windthrow susceptibility (Hanewinkel et al., 2004). Furthermore, the study of Lanquaye-Opoku and Mitchell (2005) highlighted the limited generality of region-specific, empirical regression models.

This problem is remedied by mechanistic models that deploy causal links between wind loading, tree/stand variables and the probability of damage, and quantify susceptibility in terms of a physically meaningful target variable (e.g., critical wind speed for breakage or uprooting, cf. Gardiner et al., 2008). The model ForestGALES, for instance, uses soil type and rooting depth as explanatory variables in regression models that determine resistance to uprooting (Gardiner and Quine, 2000). Peltola et al. (1999a: HWIND) employ soil bulk density and the resulting weight of the root-soil plate to model the forces counteracting uprooting. Such mechanistic approaches have been widely adopted and parameterized to model wind susceptibility (e.g., Achim et al., 2005: GALES; Nicoll et al., 2005: GALES). However, they are currently limited to predictions for structurally uniform, single species stands (see Gardiner et al., 2000). In this regard the approaches by Ancelin et al. (2004: FOREOLE) and Schelhaas et al. (2007: ForGEM-W) represent important steps towards a mechanistic calculation of critical wind speeds for complex forest canopies. Even more detailed approaches address certain aspects of tree susceptibility in particular: Chiba (2000: Sawada) used a mechanistic model based on stem bending stress to assess stem breakage in relation to stand structure, while Dupuy et al. (2007) focused on tree anchorage, modelling 3D root systems by means of a finite element model. However, where detailed mechanistic approaches are not feasible due to data or computational constraints a simple age-dependent susceptibility (where age is a proxy for height) is frequently applied (e.g., He et al., 1999: LANDIS; Schelhaas et al., 2002: EFISCEN).

\subsubsection{Occurrence}

The probability of critical wind speeds needed for damage, and thus the occurrence of damage, can be estimated based on statistical distributions (e.g., Weibull distribution) of wind speed (for each direction) using time series data from nearby weather stations (e.g., Thürig et al., 2005: MASSIMO; Schelhaas, 2008: ForGEM-W). For example, Bengtsson and Nilsson (2007) presented an approach to calculate return periods of historic storm events based on statistical extreme value theory.

An alternative empirical approach to quantify storm occurrence was presented by Canham et al. (2001: SORTIE). They simultaneously estimated local storm severity and individual tree susceptibility, exploiting the considerable variability within a windthrow event. In analogy to bootstrapping, plot-specific (i.e., the storm severity indices) and species-specific (i.e., susceptibility) parameters were sequentially refined until the most likely parameter values were identified (see also Papaik and Canham, 2006: SORTIE). Other empirical windiness scoring systems were used to predict local distribution parameters quantifying the wind regime based on altitude and position in the landscape, e.g., the Detailed Aspect Method of Scoring (DAMS) in ForestGALES (Quine and White, 1994). Several earlier analyses (e.g., Ruel et al., 1997; Suarez et al., 1999) found topographic indices to perform equally well as local wind estimates in windthrow modelling. Recently, however, Mitchell et al. (2008) confirmed the utility of mesoscale numerical weather prediction data for modelling the occurrence of windthrow events.

Local airflow models are frequently employed to simulate the occurrence of critical windspeeds, accounting for local topography (Talkkari et al., 2000: MS-Micro/3; Zeng et al., 2006: WAsP) but also allowing the evaluation of the effects of stand structure (e.g., through management) on the occurrence of critical wind speeds (Blennow and Sallnäs, 2004: WINDA; Venäläinen et al., 2004: WAsP; Panferov and Sogachev, 2008: SCADIS). Such process-based approaches to calculate the occurrence of critical wind speeds are not only useful in downscaling observed wind fields but are well suited to be applied with regional climate projections. Blennow and Olofsson (2008: WINDA) gave an example of driving a local airflow model with data from a regional climate model to assess windthrow occurrence and risk under climate change. However, the climatic influence on windthrow occurrence is not limited to wind speed. Peltola et al. (1999b) presented an approach to test climate change induced feedbacks on critical wind speed due to changes in soil frost.

\subsubsection{Impact}

The majority of wind disturbance model applications consider only potential risk based on static stand conditions or simulated stand development (as projected in a separate assessment step, e.g., using yield tables or growth-and-yield models). They thus do not model vegetation feedbacks of wind impacts explicitly. In this model class, approaches focusing exclusively on stem breakage are available (e.g., Chiba, 2000), while the widely used models ForestGALES and HWIND account for both effects of strong winds, breakage and uprooting (Gardiner et al., 2000). Changes in the predisposition of trees during a storm event (e.g., as stand structure is altered by the disturbance) are not accounted for in these approaches, however.

If feedbacks on forest structure and resources are explicitly considered (e.g., Zeng et al., 2006), trees are modelled to either die or survive a storm event unharmed in most models, despite the range of potential wind damage effects. This most common approach to model wind impacts is used in individual-based succession models (Hickler et al., 2004: LPJ-GUESS, Uriarte and Papaik, 2007: SORTIE), in grid-based state-transition models (Rademacher et al., 2004: BEFORE) as well as in empirical models (Thürig et al., 2005). The process-based model of Schelhaas et al. (2007) additionally simulates tree kills by falling neighbours. At lower resolution than the individual tree, storm impacts are modelled to "reset" agebased cohorts in a number of different cohort approaches (e.g., Frelich and Lorimer, 1991: STORM; He et al., 1999; Schelhaas et al., 2002). To account for windthrow impacts in simulations with structurally simple "big leaf" ecosystem models, a removal of biomass from the respective pools and an adjustment in respiration rate are employed (e.g., Lindroth et al., 2009: BIOME-BGC).

A simple indirect method to model storm impacts on forest ecosystems beyond tree mortality is to use descriptive damage classes as the response variable of wind damage models. For example, Boose et al. (2001) used a modified version of Fujita's (1987) 
scale, a widely applied descriptive system for assessing wind damage, which qualitatively accounts not only for stem breakage or uprooting but also for damages to leaves and branches in lower damage classes. The importance of branches and twigs and their behaviour under strong winds is, however, increasingly recognized also in mechanistic sway models (Kerzenmacher and Gardiner, 1998; James et al., 2006).

\subsection{From events to disturbance regime}

\subsubsection{Spatio-temporal dynamics}

Since the occurrence and impact of wind disturbances are strongly driven by variables extrinsic to the forest ecosystem (such as weather and topographical position), the resulting disturbance regime largely reflects these drivers; that is, in contrast to other disturbances (such as insect pests and fires), models do not usually produce the spatio-temporal patterns of wind disturbance as an emergent property of the simulation. The majority of modelling approaches to date focus on either spatial or temporal aspects of forest dynamics and storm events. A number of studies highlighted the influence of the spatial configuration of forest stands on landscape-scale wind susceptibility. Such approaches evaluate snapshots of landscape structure (e.g., Blennow and Sallnäs, 2004; Venäläinen et al., 2004) or use growth models, sometimes in conjunction with GIS software, to project stand development (e.g., Wilson, 2004: LMS; Zeng et al., 2007: SIMA; Blennow et al., 2010: FTM) as the basis for predicting susceptibility to storm events. Zeng et al. (2009: HWIND), for instance, recently corroborated the relevance of landscape configuration in their analysis based on Monte Carlo renderings of a forest landscape. However, these approaches do not model feedbacks of wind disturbance events on forest structure, i.e. wind-mediated changes of susceptibility and impacts on ecosystem dynamics are neglected.

Other approaches explicitly include wind damage effects on simulated forest development and resource trajectories. Individual-based models were used to simulate the effect of wind events on local structure and forest dynamics (e.g., Rademacher et al., 2004; Papaik and Canham, 2006; Uriarte and Papaik, 2007). Similar approaches were incorporated into models operating at larger spatial scales (e.g., Moorcroft et al., 2001: ED; Gimmi et al., 2009). Spatially explicit forest landscape models (i.e. models simulating patterns and processes at the scale of forest landscapes, i.e. typically $>10^{2}$ ha) such as LANDIS extended this approach to include explicit neighbourhood relations (i.e. contiguous blowdown areas) and species-specific susceptibilities to simulate realistic landscape patterns of wind events (He et al., 1999; Scheller and Mladenoff, 2005). However, such approaches do not currently account for the influence of neighbouring stand patterns on susceptibility to wind damage.

\subsubsection{Interactions with other disturbance agents}

As for drought, the influence of other disturbance agents on wind events is mainly limited to indirect effects, e.g., mediated by changes in age-class structure due to mortality from interacting disturbances. Such effects are explicitly modelled in the landscape approach of Scheller and Mladenoff (2005: LANDIS-II), who demonstrated the implications of wind-fire interactions on forest succession. Disturbance agents like fungi and pathogens also have the ability to influence the resistance of trees to breakage and windthrow. Papaik et al. (2005: SORTIE) implemented this interaction in their individual-based vegetation modelling approach by distinguishing wind susceptibility parameters for different levels of pathogen infection. Their simulations highlighted the influence of pathogens on windthrow and subsequent vegetation development.

\section{Forest fires}

\subsection{Modelling forest fire events}

\subsubsection{Susceptibility}

Susceptibility to fire depends on the properties of living and dead vegetation as fuel, i.e. its amount and spatial distribution, which are related to forest composition and structure. Fuel properties are frequently summarized in fuel models (i.e. a multi-attribute characterization of fuel traits used to predict fire behaviour). Different concepts have been developed (cf. Arroyo et al., 2008), with approaches ranging from fuel types with inherent characteristics for empirically-based models (e.g., Forestry Canada, 1992; Fernandes et al., 2009) to a detailed description of fuel properties for semi-physical and physical models, e.g., fuel load by size class and condition (dead or alive), fuel depth, the ratio of surface area to volume, energy content and fuel moisture (e.g., Rothermel, 1972).

In contrast to the static characterisation in fuel models dynamic estimates of fuel characteristics can be derived from vegetation models. Simple representations are based on age since the last fire as a proxy for fuel accumulation (e.g., Li et al., 1997) or employ fuel accumulation curves (Cary and Banks, 1999; Hall et al., 2006). In this regard Zinck and Grimm (2009), bridging the gap between ecological and physical fire models, recently demonstrated the key importance of ecological legacy in fire systems. More complex dynamic vegetation models employ state-transition approaches (Keane et al., 1996: FIRE-BGC), they simulate age cohorts (Mladenoff and He, 1999: LANDIS) or individual trees (Miller and Urban, 1999: ZELIG; Schumacher et al., 2004: LANDCLIM) explicitly. The latter fine-grained dynamic approaches not only track fuel dynamics and accumulation, but also provide indicators of vertical fuel structure (e.g., canopy base height, foliar density), an important input for the simulation of crown fires (van Wagner, 1977; Cruz et al., 2005).

\subsubsection{Occurrence}

Fire ignition modelling can be tackled stochastically or deterministically, the latter harnessing density distributions to quantify fire occurrence. The spatial scale of such distribution-based approaches varies from fine-scale grids (Cardille et al., 2001) to broad aggregation for administrative entities (de la Riva et al., 2004; Martinez et al., 2009) or ecological regions (Chou et al., 1993; Wotton et al., 2003), while multi-scale approaches were presented by Díaz-Avalos et al. (2001) and González-Olabarria et al. (2010). A Weibull distribution is an example for a flexible approach to characterize fire occurrence for a given location (e.g., Moritz et al., 2004).

If a fire event is to be simulated explicitly, the highly complex interactions between fuel, weather, topography, and society are most commonly embraced implicitly in a stochastic approach, e.g., based on fire ignition probability (Martell et al., 1987; Cardille et al., 2001; Martinez et al., 2009). Alternatively, the use of fire frequency (instead of fire ignition probability) was suggested by Malamud et al. (2005), accounting for the fact that there are many more minor, undetected ignitions than "relevant" fires. Most natural fires are caused by lightning strikes, and hence the frequency and type of electric storms in a region are important drivers in such models (Rorig and Ferguson, 1999). Human-caused ignitions depend on the presence of people and their respective activities. Fire ignition as a function of human and/or biophysical explanatory variables is often modelled using generalized linear models such as logistic, Poisson or negative binomial regression (e.g., Wotton et al., 2003; Martinez et al., 2009; Syphard et al., 2008), generalized linear mixed models (Díaz-Avalos et al., 2001; González-Olabarria et al., 2010), through direct gradient analyses (e.g., Viedma et al., 2009), weight of evidence (e.g., Romero-Calcerrada et al., 2008), 
using neural network models (e.g., Vega-García and Chuvieco, 2006), or fuzzy logic (Loboda and Csiszar, 2007). However, many widely applied dynamic landscape models, simulating individual fire events explicitly, are based on descriptive parameters of the fire regime only, e.g., average return intervals and maximum (and sometimes also minimum) fire sizes (e.g., Mladenoff and He, 1999). More recently an increasing number of models were presented in which fire occurrence is predicted as an emergent property of the interactions between climate, vegetation and human impacts (e.g., Schumacher et al., 2006: LANDCLIM; White et al., 2008: LAFS; Kloster et al., 2010: CLM-CN).

Once a fire is ignited, its behaviour is not just a function of the nature, amount and spatial distribution of fuels (see above), but it is also influenced by weather (wind, relative humidity, ambient temperature, solar radiation) and topographical conditions (slope, aspect). Models explicitly simulating fire behaviour frequently use fire weather indices (e.g., Deeming et al., 1972; van Wagner and Pickett, 1985) to account for the effects of recent weather conditions on fuel moisture, in addition to considering actual weather and its effect on fire behaviour. Since, in contrast to other disturbance agents, humans have an active role in the occurrence and development of many forest fires, also anthropogenic components have to be considered in explicit fire behaviour modelling (cf. Weibel et al., 2010). Fire modelling tools such as FARSITE (Finney, 1998) and BehavePlus (Andrews, 1986; Andrews et al., 2004) simulate fire behaviour at the stand- or landscape-level from fuel, weather and topography. They can be applied to predict the behaviour of an individual fire event in detail or to generate process-based fire vulnerability maps (e.g., Keane et al., 2010: FIREHARM). Such dynamic spatial simulation models addressing fire behaviour explicitly have been increasingly presented and applied over the last years (Cary et al., 2006, 2009; Finney et al., 2007: FVS; King et al., 2008: FIRESCAPE). For an in-depth discussion of the merits of alternative approaches to fire behaviour modelling we refer to Sullivan (2009).

\subsubsection{Impact}

First order fire effects on forest vegetation (i.e. fire severity) are mainly a function of the amount and rate of heat release (i.e. fire intensity, see review in Michaletz and Johnson, 2007). Although physically-based models of heat transfer to live tissue have recently been developed (Bova and Dickinson, 2005; Michaletz and Johnson, 2006), the most common approaches in current tree mortality models are still largely empirical (Peterson and Ryan, 1986; Fernandes et al., 2008). Such approaches use data on fire-induced injury and individual tree traits (e.g., tree diameter, bark thickness) as descriptors to model the probability of post-fire tree mortality. Indicators of fire injury can be derived from direct observations such as crown scorch height or volume, crown consumption, stem char height, bark char depth and forest floor consumption (Ryan and Reinhardt, 1988; McHugh and Kolb, 2003; Rigolot, 2004; Varner et al., 2007), or they can be established indirectly through fire behaviour (Beverly and Martell, 2003; Kobziar et al., 2006; Schwilk et al., 2006). For the latter, flame size or fire intensity can be translated into crown injury through crown scorch height models (e.g., van Wagner, 1973).

In contrast, second order fire effects, such as post-fire vegetation response, may be independent of severity (e.g., Keeley, 2009). Many fire-adapted species have the ability to sprout from below-ground parts after a fire event. A vital attributes approach (cf. Krivtsov et al., 2009) can been used to model such plant responses (Noble and Slatyer, 1977). At the community level, vegetation impacts of fire are frequently modelled using a rule-based representation of vegetation changes, e.g., as transition to early seral communities (Kurz et al., 2000: TELSA) or alternative vegetation types (Rodrigo et al., 2004). In simulation models keeping track of a higher level of detail in vegetation structure, fire impacts are modelled by resetting the age matrix (Li and Barclay, 2001: SEM-LAND) or killing individual trees (Keane et al., 2001) - a high-resolution vegetation modelling component is thus a prerequisite for a detailed modelling of fire impacts.

\subsection{From events to disturbance regime}

\subsubsection{Spatio-temporal dynamics}

Climate, fuel, landform and human activity interact in a complex manner to determine the spatio-temporal characteristics of a fire regime (Falk et al., 2007). Descriptive statistical approaches frequently used to characterize this landscape-scale heterogeneity are fire size distributions (e.g., Vázquez and Moreno, 2001; DíazDelgado et al., 2004; Rollins et al., 2004), e.g., often following a power law (e.g., Moritz et al., 2005). Others have concentrated solely on the statistical analysis of extreme events in the context of fire size (Moritz, 1997; de Zea Bermudez et al., 2009). Embracing spatial heterogeneity, models can be used to study fire incidence with regard to the null hypothesis of random occurrence across landscapes (e.g., Mermoz et al., 2005; Bajocco and Ricotta, 2008). How fire occurrence differs for land cover categories and spatial patterns within a landscape was modelled based on a resource selection function approach (e.g., Moreira et al., 2001, 2009; Lloret et al., 2002; Mermoz et al., 2005) and a kernel density approach combined with a classification tree analysis (Amatulli et al., 2006). The latter method has recently also been applied to study fire severity within a landscape (Alexander et al., 2006; Lee et al., 2009; Thompson and Spies, 2009).

To simulate spatio-temporal characteristics of forest fires in a fully dynamic framework, two general scopes of application can be distinguished (cf. Li et al., 2008). Fire event simulators, as described above, operate on a high temporal resolution to provide detailed predictions of the spatio-temporal development of a fire, but they usually have a short-term focus. Algorithms to simulate fire spread in such models are, for instance, Huygen's wavelet propagation (Anderson et al., 1982; Finney, 1998), Dijkstra labelling in which spread is modelled according to the heuristic shortest paths (e.g., Kourtz et al., 1977), or a system of partial differential equations (Richards and Bryce, 1995; Richards, 1999). Focused more on the long-term dynamics of fire regimes, forest landscape models mostly use less complex approaches to simulate fire spread, such as applying a predetermined fire perimeter ("cookie cutter") or lattice model approaches, including cellular automata and bond percolation spread models (cf. Keane et al., 2004).

The relative influence of weather, fuel and management-related variables on the spatio-temporal dynamics of wilfire is a "hot topic" that is increasingly examined through landscape fire models (Venevsky et al., 2002; Thonicke and Cramer, 2006; LaCroix et al., 2008; Cary et al., 2009; Parisien and Moritz, 2009). Schumacher et al. (2006), for instance, were able to reproduce key features of the fire regime along a large altitudinal gradient in the Rocky Mountains based on climatic and topographical data alone. However, ongoing research showed that it may not be possible to directly apply a model that is successful in one region to other regions (Weibel, 2009). These issues of generality and spatio-temporal interactions are thus of particular importance for addressing emergent questions in relation to climate change, forest management and the fire regime.

\subsubsection{Interactions with other disturbance agents}

A number of disturbance agents dynamically interact with forest fire regimes at various scales (Stocks, 1987; Allen, 2007; Woodall and Nagel, 2007). Dry conditions are a prerequisite for significant fire events, and drought indices are thus a key component of forest fire weather indices. Statistical regression approaches to model the drought-fire relationship have been presented recently, e.g., by 
Girardin and Mudelsee (2008), Amiro et al. (2009), and Weibel et al. (2010). However, generally dry climate conditions also reduce productivity and thus fuel availability, exerting a negative feedback on fires. This complex interaction between intensification and relaxation, requiring a process-based representation of both vegetation and fire processes, has been modelled only rarely to date, e.g., by $\mathrm{Ni}$ et al. (2006) who used the process-based dynamic global vegetation model LPJ-DGVM.

Storm events as well as attacks from insects or pathogens can kill trees and break branches, thus increasing the fuel load and influencing burn extent and severity. These effects were modelled statistically applying logistic regression approaches (e.g., Fleming et al., 2002; Bigler et al., 2005; Sieg et al., 2006), classification tree models (Kulakowski and Veblen, 2007) as well as Markov chain Monte Carlo approaches (Lynch et al., 2006). Notably, Lundquist (2007) used a structural equation modelling approach to assess the effect of numerous disturbance agents on fuel loading, finding the greatest interactions for wind (indirect) and root rot (direct). Such approaches, going beyond the consideration of independent individual predictors and allowing the examination of simultaneous and interacting influences, are particularly valuable to gain insight into the complex interactions that are characteristic for disturbance regimes.

Disturbance interactions were also incorporated in biophysical models of fire behaviour, accounting for their effects on fire intensity and crown fire likelihood. Custom fuel models for Rothermel's surface fire spread model were for instance developed for different stages of a bark beetle outbreak cycle (Page and Jenkins, 2007; Jenkins et al., 2008). Reich et al. (2004) combined multiple ordinary least squares regression models and binary regression tree analysis in a two-stage approach to derive fuel models accounting for the effects of other small-scale disturbances on fuel loading. While fire behaviour models, relying on such fuel models, are mostly used to assess particular events or project landscapes under given conditions, the long-term effects of insect-fire interactions on stand development trajectories were for instance addressed by employing the Forest Vegetation Simulator (FVS) as a predictive platform in combination with extensions for fire and insects (e.g., Hawkes et al., 2005; Coleman et al., 2008). Trading off process resolution for scale, these interactions were modelled via changed vegetation structure and composition at larger scales by means of state-andtransition approaches (e.g., Bachelet et al., 2000: MC1; Kurz et al., 2000: TELSA), and cellular automata (e.g., He and Mladenoff, 1999; Shifley et al., 2006: LANDIS). Despite the substantial ecological and management implications of wildfire disturbance interactions (e.g., Axelson et al., 2009) and the potential of models for addressing them, limited process understanding and demanding scaling requirements (from the level of small-scale fuel conditions to decades and centuries of landscape dynamics) still pose a challenge for simulation modelling and make disturbance interactions an active field of research and debate.

\section{Insects}

\subsection{Modelling insect attacks}

\subsubsection{Susceptibility}

The susceptibility of forests to insect attack and damage is largely determined by environmental factors and specific features of stands and individual trees (Berryman, 1986; Speight and Wainhouse, 1989; Fettig et al., 2007). Forest management, manipulating the latter aspects, significantly affects the susceptibility to insect pests (e.g., Veteli et al., 2006; Fajvan et al., 2008; Jactel et al., 2009). The potential influence of vegetation attributes is best illustrated by tree-based classifications according to a set of dis- criminating variables, often including stand basal area or specific tree properties (Reynolds and Holsten, 1996; Negrón and Popp, 2004). Logistic regression models are commonly used to predict probabilities (e.g., likelihood of attack) as a function of susceptibility indicators at the stand and tree level (Perkins and Roberts, 2003; Magnussen et al., 2004; Negrón et al., 2008, 2009). Examples of comprehensive susceptibility models were given by Wulder et al. (2006) for Dendroctonus ponderosae (Hopk.) and by Luther et al. (1997) for Acleris variana (Fern.). Ogris and Jurc (2010) recently presented a correlation model using a multivariate regression tree to predict potential sanitary fellings of bark beetle-attacked Norway spruce based on 21 climate, soil and forest variables. Despite several restrictions, such as the high demands regarding data quality or the limited geographical transferability, such multiple linear regressions continue to be widely used. The local evaluation of site and stand characteristics as indicators of stand susceptibility based on discriminant analysis may also be insightful for incorporation into more general process models (e.g., Shore et al., 1999; Dutilleul et al., 2000). In this regard, however, work by Park and Chung (2006) suggested alternative analysis approaches, demonstrating the high capacity of artificial neural networks to predict tree death or survival following the attack of Thecodiplosis japonensis (Uch. et Inou.).

Another family of modelling concepts explicitly addresses host susceptibility, i.e. how the physiological status of the host influences the risk for insect attacks. The plant stress hypothesis states that insects feeding on mature plant tissue are favoured by environmental situations that are stressful to the host (White, 2009), while the plant vigour hypothesis states that insects feeding on newly produced plant tissue are favoured by conditions beneficial for biomass production (Price, 1991). Thus, tree vigour or relative tree growth rate have been used as proxies for tree resistance or susceptibility to insect attacks (Waring and Pitman, 1983; MünsterSwendsen, 1984; Baier, 1996; Negrón, 1997). For example, models of tree physiology were applied to predict variations in vigour associated with climate characteristics (e.g., Coops et al., 2005, 2009: 3-PG).

However, herbivore-host interactions in the form of tree defence mechanisms, not considered in the previously described approaches, are crucial for the susceptibility to many biotic disturbance agents. Larsson et al. (2000), examining the conditions triggering outbreaks of Neodiprion sertifer (Geoff.), analysed how interactions between individual insects and the host plant will translate into effects at the population level. They found that even small changes in needle resin concentration may have a significant impact on population growth. Resin capacity of trees was also found to serve as a simple descriptor of tree resistance in a mathematical model of chemical ecology and spatial interaction between $D$. ponderosae and its hosts (Logan et al., 1998).

\subsubsection{Occurrence}

Insects are ectothermic organisms, and their distribution is thus strongly influenced by weather and climate. Several statistical modelling techniques, commonly referred to as bioclimatic envelope models, have been developed for assessing the geographical distribution of species as a function of climate variables (see review by Heikkinen et al., 2006). The CLIMEX modelling framework, for instance, was applied to different insect species (Sutherst and Maywald, 1985; Sutherst et al., 2000; Vanhanen et al., 2007). Other approaches include panel data modelling for fitting of regression models (Gan, 2004). Bioclimatic models assume an equilibrium of the modelled distribution with climate conditions, and time lags of species dispersal are rarely accounted for (Heikkinen et al., 2006), which creates uncertainties in projections of future species distributions (Mitikka et al., 2008). To reduce uncertainties associated 
with individual model concepts, a combination of approaches has been advocated (Araújo and New, 2007).

Phenological models (i.e. models of insect life cycle events) employ species- and life stage-specific temperature requirements towards a more process-based representation of an insect's climate dependency (Gaylord et al., 2008). Such approaches have been developed for important insect pest species, such as Ips typographus (L.) (Wermelinger and Seifert, 1998; Netherer and Pennerstorfer, 2001; Netherer and Nopp-Mayr, 2005; Baier et al., 2007: PHENIPS; Jönsson et al., 2007, 2009) and Lymantria dispar (L.) (Logan and Bentz, 1999; Gray, 2004; Powell and Logan, 2005; Pitt et al., 2007). Incorporating species-specific diapause regulation into such models was found crucial for predicting the response to driving climate variables (Gray et al., 2001; Steinbauer et al., 2004; Dolezal and Sehnal, 2007; Tobin et al., 2008). However, since detailed experimental knowledge on the phenology of many insect species is lacking, frameworks for the explorative analysis of weather impact on insect life cycle stages over space and time were proposed to facilitate phenological modelling (Jarvis, 2001). Furthermore, insect phenology may change in response to environmental changes, which is rarely considered in current phenological models. To predict the amount and rate of such changes, genetic variation and selection pressure have been suggested as suitable indicators (van Asch et al., 2007).

Numerous herbivore insect species are typically present at low levels in a forest ecosystem, but only a mass outbreak makes them a disturbance with major impacts on forest vegetation. Weather and climate can be used as predictors for the probability of mass outbreaks, as specific weather situations commonly serve as triggers influencing host tree susceptibility and/or insect performance. Successful modelling requires the identification of key processes regulating the species-specific outbreak dynamics. The outbreak potential of certain bark beetle species (e.g., Dendroctonus frontalis (Zimm.), Ungerer et al., 1999, and D. ponderosae, Régnière and Bentz, 2007), for instance, is regulated by winter survival, thus low winter temperatures are among the most important factors for modelling the large-scale pattern of their epidemics. Other insects, such as I. typographus, require ample brood material with severely reduced defence capacity in addition to favourable weather conditions in order to reach an epidemic population size, i.e. being able to attack living trees (Christiansen and Bakke, 1988; Fettig et al., 2007). To capture these dynamics, a process-based model describing the build-up and depletion of resources (i.e. host trees) at the landscape level was developed by Økland and Bjørnstad (2006). Large-scale temporal correlations in weather and habitat controls were found to be responsible for the spatially synchronous outbreaks of insect pests (Peltonen et al., 2002; Økland et al., 2005). To investigate the relative importance of these processes, Powers et al. (1999) applied a multi-scale approach including point-pattern analysis, regression analysis and timeseries analysis of the outbreak dynamics of Dendroctonus pseudotsugae (Hopk.). To simulate the effects of future weather and habitat conditions on outbreak characteristics (duration, severity and consistency), Gray (2008) used constrained ordination regression for the case of Choristoneura fumiferana (Clem.) outbreaks in Canada.

The challenge of modelling full-scale insect population dynamics requires integration over processes and scales, combining information about host and insect sensitivity to weather, timing of life cycle processes, reproductive success and mortality. Examples were presented by Wilder (1999), predicting the timing and magnitude of $L$. dispar outbreaks based on egg and larval performance, and Régnière and Bentz (2007), mechanistically modelling the regulation of population dynamics by density independent winter mortality and stage specific cold-tolerance. An important aspect in modelling population dynamics are the regulatory effects of predators and parasitoids (e.g., Mills and Getz, 1996; Abbott and Dwyer, 2007; Berggren et al., 2009). Modelling insect population dynamics is a particularly valuable approach in the context of pest control, where models were developed to simulate pheromone trap efficiency (Byers, 1993), bark beetle flight behaviour (Byers, 1996) and the risk of outbreaks based on pheromone trap records (Faccoli and Stergulc, 2004, 2006). In this context Bogich and Shea (2008) have recently demonstrated the utility of a metapopulation approach in determining optimal management strategies along an outbreak front of L. dispar.

\subsubsection{Impact}

The direct impacts of insect herbivory on tree physiological traits are frequently simulated explicitly for defoliators. Statistical models such as multiple linear regression and nonlinear regression models were employed to estimate defoliation (i.e. loss of leaf area) based on stand and environmental descriptors (e.g., Davidson et al., 2001; Wolf et al., 2008: GUESS; Komonen and Kouki, 2008). Similar statistical approaches were used to directly model tree growth reduction in response to defoliation (e.g., Mason et al., 1997; Pothier et al., 2005; Campbell et al., 2008). With regard to insect herbivory on phloem rather than on foliage, the Westwide Pine Beetle Model (Smith et al., 2005; Ager et al., 2007: FVS) represents a processoriented approach in which the beetle occupation level necessary to kill one square foot of basal area is used as a proxy for the physiological effects of phloem feeding. More detailed processbased models explicitly take into account the nesting population density per tree as well as tree defence and recovery (Logan et al., 1998). In addition, carbon balance approaches were applied to model physiological effects of phloem feeding (Dungan et al., 2007).

The vast majority of models including insect disturbances, however, simulate their impact on vegetation simply in terms of tree mortality. Statistical analyses by means of regression models corroborate the relevance of the local environment and individual tree characteristics as predictors of insect-related tree mortality (e.g., Negrón et al., 2001; Doak, 2004; Fabrika and Vaculčiak, 2009: SIBYLA). Nonetheless, statistical models were also developed at the stand level, using multiple linear or logistic regression as well as classification and regression tree models (Negrón, 1998; Eisenbies et al., 2007; Pothier and Mailly, 2007). To stratify stand level estimates and identify weakened or preferred host individuals, tree characteristics and configuration are frequently used (Lexer and Hönninger, 1998; Seidl et al., 2007: PICUS; Ager et al., 2007). Also population levels were considered in modelling stand level host tree selection, i.e. accounting for a changing host size with increasing insect pressure (Smith et al., 2005; Ager et al., 2007). In a detailed mechanistic framework, such insect-host relations can be modelled as colonization-dependent attractor-repellent functions of pheromones, as shown by Logan et al. (1998) for $D$. ponderosae.

\subsection{From events to disturbance regime}

\subsubsection{Spatio-temporal development}

The temporal dynamics of insect herbivory and its potential feedbacks on ecosystem processes can be studied by integrating such agents into dynamic ecosystem models. Defoliation effects, for instance, were included into physiological "big leaf" models via simple defoliation ratios or linear models depending on host availability (Hogg, 1999: FOREST-BGC; Wolf et al., 2008). Accounting for disturbance effects in country-scale resource assessments, Kurz et al. (1992) and Kurz and Apps (1999) developed a distribution-based approach based on long-term disturbance records (CBM-CFS), recently refined with regard to insect disturbances (Kurz et al., 
2009). In another country-scale study, Seidl et al. (2009) applied a statistical meta-modelling approach to upscale process-based estimates of bark beetle mortality in the large-scale forest scenario model EFISCEN.

While all these approaches account for the dynamic feedbacks between forest vegetation and disturbances over time, they do not simulate the spread and spatial pattern of insect disturbances explicitly. Approaches that focus on the latter aspect include statistical pattern detection and generation (Gray et al., 2000; Edgar and Burk, 2007). In simulation modelling cellular automaton approaches are frequently applied to keep track of spatial dependencies (Bone et al., 2007; Lee et al., 2007). Recently, Zhu et al. (2008) presented a process-driven statistical approach to simulate bark beetle mortality events in a spatially explicit manner, using univariate, spatio-temporal Markov random field models to incorporate both spatial and temporal effects. Embracing a metapopulation view, an elegant solution to modelling spatiotemporal dynamics was presented by Bogich and Shea (2008). Focusing on a moving window along the main outbreak front, they modelled spatial dynamics with a finite state-space of a traceable number of patches. Using a dynamic state variable approach, Chubaty et al. (2009) simulated spread and colonization of $D$. ponderosae as an emerging property of behavioural decisions aimed at maximizing colonization success while accounting for energy and time constraints.

Some forest landscape models are explicitly designed to address the interactions between insect and forest dynamics over time and space. Processing stand level simulation entities in parallel and allowing between-stand contagion at every simulation time step was an early approach to address landscape dynamics (Crookston and Stage, 1991; Crookston and Dixon, 2005: FVS). Cellular automaton approaches are used widely to simulate spatial spread of insect disturbances across forest landscapes. They allow a flexible implementation of spatial interactions and vegetation feedbacks at various levels of process resolution, ranging from disturbance-mediated vegetation state transition probabilities accounting for neighbourhood effects (Kurz et al., 2000: TELSA) to models explicitly tracing insect-host interactions and their respective life cycles (Sturtevant et al., 2004: LANDIS-II; BenDor et al., 2006).

\subsubsection{Interactions with other disturbance agents}

A large number of insect disturbance agents are highly sensitive to other disturbances, and outbreaks are in many cases linked to triggering events such as windthrow or drought. Models of such interactions mainly focused on descriptive, statistical approaches, including various logistic regression models (Bebi et al., 2003; Bigler et al., 2005; Breece et al., 2008), generalized linear models with different link functions (Peltonen, 1999; Eriksson et al., 2005; Hood and Bentz, 2007) and classification tree models (Kulakowski and Veblen, 2007). As an alternative approach for evaluating hypotheses and conceptual understanding about fire-bark beetle interactions, Youngblood et al. (2009) demonstrated the utility of structural equation modelling. In a more process-oriented approach Seidl et al. (2007) used a dynamically calculated estimate of drought-induced host tree stress to account for increasing tree susceptibility to I. typographus attack. Moreover, resource depletion approaches were used to study population effects of windthrow events for this important European bark beetle species (Økland and Berryman, 2004; Økland and Bjørnstad, 2006). The indirect influence of other disturbance agents on insects via a changing habitat and host tree distribution was assessed using landscape modelling approaches, e.g., for fire effects on bark beetles (Li et al., 2005: SEM-LAND) as well as for fire effects on defoliators (Bouchard and Pothier, 2008).

\section{Ungulate browsing}

\subsection{Modelling browsing events}

\subsubsection{Susceptibility}

The impact of browsing on forest dynamics depends on the identity and density of ungulate populations and their food choice, as well as on the species-specific resistance of tree saplings (Boulanger et al., 2009). Many tree species have developed chemical and mechanical defences against browsing from large herbivores (Massei et al., 2000), but also fast growth can mitigate the impact of browsing events by enhancing the replacement of lost material or reducing the time during which small saplings are susceptible.

In many forest models that account for the effect of ungulates, the species-specific resistance or susceptibility of tree saplings is considered to be constant; they thus address the above mentioned processes in a highly aggregated fashion. For example, in forest gap models browsing is frequently implemented by means of an ordinal or continuous susceptibility parameter, reflecting palatability and browser preference for saplings of a certain size (Seagle and Liang, 2001: ZELIG; Wehrli et al., 2007: FORCLIM). Rammig et al. (2007) used a species-specific browsing probability index to study the effect of browsing in a grid-based vegetation model. Other approaches incorporated the selection of specific plant species by ungulates in relation to the relative abundance of plant biomass (Jorritsma et al., 1999: FORGRA). Recently, Vospernik and Reimoser (2008) and Reimoser et al. (2009) developed a GIS-based statistical model to predict habitat suitability for roe deer and predisposition for browsing damage in spruce-dominated forests in Austria, using terrain, understorey vegetation and forest stand properties as predictors.

\subsubsection{Occurrence}

In most forest models browsing occurrence and intensity are assumed to be constant over space and time. Wehrli et al. (2007), for instance, introduced a lumped, site-specific ordinal factor for browsing intensity and occurrence in FORCLIM, which in combination with the respective susceptibility parameter results in browsing impact. For white-tailed deer browsing in an Eastern North American riparian hardwood forest, Seagle and Liang (2001) used a more detailed two-stage approach to modelling browsing probability, accounting for both density of tree regeneration (considering seedlings and saplings less than $2 \mathrm{~cm}$ diameter) and an ungulate density index. Occurrence and intensity were determined by species-specific browsing factors as functions of the species' relative densities and browsing preference rank.

When high-quality data on browser density as well as browsing occurrence and intensity are available, as is the case for many domestic ungulates (e.g., goats, horses, cattle), detailed mechanistic models can be developed. Such models are particularly relevant to better understand the impacts of heavy herbivore pressure experienced by many natural and managed forests in Europe in the recent past. For example, Weber et al. (2008) enhanced the gap model FORCLIM by incorporating a better understanding of the palatability and susceptibility of two tree species, simulating domestic goat grazing based on land-use history. Gillet (2008: WoodPaM) developed a mosaic model of vegetation dynamics in silvopastoral landscapes, in which local browsing occurrence and intensity is deduced from the frequency of cattle visits to each cell, depending on its attractiveness (e.g., slope, tree cover, forage availability) and overall stocking density.

\subsubsection{Impact}

At the individual plant level, browsing can be a severe perturbation for palatable trees, resulting in loss of foliage and twigs or damages to stems, and thus affecting growth and eventually also 
leading to mortality. Tester et al. (1997) used a frame-based modelling paradigm to assess how such "external" drivers affect forest succession. Their study showed that browsing, depending on its effect on vegetation in conjunction with other factors, can result in the transition from one successional stage to another. Studying a related objective, Gillet et al. (2002: PATUMOD) used a compartment model to evaluate browsing impacts on vegetation in a forested ecosystems subject to high browsing pressure.

In certain forest gap models the rate of tree establishment is partially determined by browsing intensity, which acts as a filter upon the probability of tree regeneration (i.e. browsing-induced mortality is intrinsically accounted for by reduced species-specific establishment probabilities rather than being considered explicitly). Weber et al. (2008) refined this approach by implementing a boolean auxiliary variable that either allows or prevents seedling establishment, depending on browsing pressure within the patch and the species' susceptibility to browsing. In contrast, Seagle and Liang (2001) implemented species-specific browsing intensity explicitly as a modifier reducing sapling growth, thus increasing the probability of mortality (while not assuming direct browsinginduced mortality). They demonstrated the utility of their approach for simulating vegetation impacts of different deer population levels on long-term successional trajectories in riparian hardwood forests.

More explicit approaches, in which browsing leads to a reduction in tree height or the consumption of entire saplings, were presented by Rammig et al. (2007) and Jorritsma et al. (1999). Such approaches allow for the incorporation of tree-size specific mortality rates associated with browsing, i.e. small saplings are not as resistant to browsing as taller trees. Another important interaction for modelling browsing impacts exists with light availability and tree growth, as shading directly affects sapling growth and thus the time needed for trees to outgrow highly vulnerable development stages (Wehrli et al., 2007). In this regard Weisberg et al. (2005: HUNGER) presented an approach that models the interaction of light availability and browsing impact. Their physiological model furthermore simulates the partitioning of carbon and nitrogen to shoot and root tissue, a critical process for simulating realistic responses to browsing events. Two forms of browsing, lateral and top-down, are considered simultaneously and independently as stochastic processes in their model.

For modelling the impact of Sika deer browsing on hardwood forests in Japan, forest dynamics were added to an existing herbivore-vegetation model by Akashi (2009). This deterministic approach incorporating both forest and deer population dynamics proved insightful in studying the resilience of forest vegetation to browsing, the effect of browsing on equilibrium states of the vegetation, the effect of unpalatable plants on plant-herbivore dynamics as well as the interaction between herbivore and plant population dynamics.

\subsection{From events to disturbance regime}

\subsubsection{Spatio-temporal dynamics}

Most of the models reviewed above apply a time step of one year. An exception is the FORGRA model of Jorritsma et al. (1999), which uses a monthly time step to account for seasonal variation in forage availability and species composition. Detailed physiological models (e.g., Weisberg et al., 2005) use process-dependent time steps ranging from 0.1-day to one year, and their spatial grain of operation may be as small as 0.001 ha. While such approaches are typically applied at decadal time frames, gap models, which operate at the scale of a gap created by the death of a large canopy tree (typically $0.01-0.1 \mathrm{ha}$ ), are explicitly designed to evaluate long-term (i.e. several hundred years) interactions of browsing and vegetation dynamics (Seagle and Liang, 2001; Weber et al., 2008). While these approaches simulate vegetation-disturbance dynamics over time, they are not spatially explicit.

With regard to the latter aspect Rammig et al. (2007) presented a spatially explicit grid-based vegetation model with a grain of $1 \mathrm{~m}^{2}$, incorporating browsing effects to simulate post-disturbance vegetation development. In a follow-up study, Rammig and Fahse (2009) demonstrated the importance of considering spatial vegetation patterns when simulating browsing impacts. At lower resolution, Kirby (2004) developed a simple spatially explicit stateand-transition model to explore Vera's hypothesis (Vera, 2000) of long-term patch dynamics driven by wild large herbivores in natural lowland forest landscapes. Based on the assumption that grazers and browsers were more diversified and abundant in the past, results indicate a browsing-mediated 500-year cycle of successional vegetation phases (grove, break-up, park, scrub).

Seagle and Liang (2001) suggested that in addition to the spatially explicit distribution of trees also the landscape-scale population dynamics of herbivores should be incorporated into ecosystem models. Such an integration of approaches to model deer population dynamics and forest succession at the landscape scale (cf. Weisberg et al., 2006) would be able to account for the threedimensional hierarchy that is important for the spatio-temporal dynamics of browsing in forest ecosystems: Deer browsing in forests is determined by the distribution of saplings in the landscape, deer densities affect the regeneration dynamics of trees, and the species-specific selectivity of deer browsing influences forest composition over time. Ungulate-vegetation interactions need to be better understood over multiple scales, using a more system-oriented approach to comprehensively address the direct and indirect effects of ungulates on communities, ecosystems and landscapes (Weisberg and Bugmann, 2003). The importance of modelling the spatio-temporal interactions among browsers, tree populations, shrub and herb communities was underlined by Gillet (2008), demonstrating that a shifting mosaic of silvopastoral communities at the landscape scale can emerge from a mechanistic compartment model.

\subsubsection{Interactions with other disturbance agents}

State-and-transition models can be used to simulate the change in vegetation states across single or multiple successional pathways, and can incorporate the interaction of disturbances such as fire, drought, insect outbreaks, herbivory and diseases (e.g., Hemstrom et al., 2007; Strand et al., 2009: VDDT). At finer process resolution, the spatially explicit, process-based approach of Kramer et al. (2003: FORSPACE) focuses on the interaction between ungulate browsing and fire on forest dynamics at the landscape level. The interaction of these two disturbances was assessed by evaluating foliage biomass against ungulate biomass. To evaluate the effect of browsing on the extent of fires, the areas affected by fire under different scenarios of fire frequency and ungulate densities were compared for both the herb and tree layers.

To some extent, forest management may act in the same manner as large scale disturbances, and Kramer et al. (2006) found clear spatial interactions between forest management and ungulate browsing, with small-scale mosaic-type variation illustrating the importance of fluctuating herbivore density in relation to forest type and forest management. Rammig et al. (2007) simulated the regeneration of a subalpine forest after a major windstorm and explored how varying browsing pressure affects re-vegetation. By reducing tree height ungulate browsing resulted in trees being exposed for longer time periods to extreme conditions in the blowdown area, thus leading to increased tree mortality. In a recent statistical approach, Eschtruth and Battles (2008) modelled the effect of insect-related decline on ungulate herbivory, finding higher herbivory impacts and changes in affected species as a result of the interaction. However, to date disturbance interactions are 
rarely accounted for in studies of ungulate herbivory (Wisdom et al., 2006).

\section{Discussion and conclusion}

\subsection{Concepts in modelling natural disturbances}

In Sections 3-7 we have reviewed the variety of approaches available for the modelling of five natural disturbance agents. The subset of the literature analyzed for this review (324 unique references) clearly reflects the increasing recognition and importance of disturbances in forest ecology and management over the last 15 years, as well as the growing capacity of models to address these complex processes (Fig. 2a). Our analysis showed that the large majority of approaches reviewed (68.5\%) address mechanisms pertaining to disturbance events (i.e. susceptibility, occurrence and/or impact, see Online Supplement for data and methodological details). Modelling higher-level aspects of disturbance regimes, such as spatio-temporal dynamics and interactions, have received increasing attention only in recent years, facilitated by a focus on landscape scale processes in ecology (Turner, 2005).

To synthesize general disturbance modelling concepts from the reviewed literature we analysed approaches with regard to the aspects (i) process representation (i.e. along a gradient from descriptive statistical models to predictive process-based approaches), (ii) emergence and feedbacks of disturbance dynamics (i.e. are disturbance events emerging from the modelled system, or are they imposed externally; and are dynamic feedbacks on vegetation considered), and (iii) integration into ecosystem simulation (i.e. which aspects of ecosystems, e.g., vegetation structure, composition, physiology, landscape patterns, are affected by disturbances in the model). Based on the seven general concepts thus synthesized (Table 2) we find that the single most common concept used is statistical modelling (42.3\%). Particularly with regard to modelling individual disturbance events in detail (Fig. 2b) we are only gradually progressing from descriptive modelling to more process-oriented approaches. Furthermore, also the ability to capture dynamic interactions in models and simulate disturbances as emerging properties of the system (cf. Railsback, 2001) remains limited, despite its great importance for predictive modelling, e.g., under novel future climate conditions. Our review showed that process-based approaches including such dynamic feedbacks are still relatively rare, particularly for the simulation of vegetation susceptibility and disturbance occurrence (see Fig. 2b). Promising examples have been presented particularly pertaining to biotic disturbances, e.g., explicitly considering population dynamics of the disturbance agent (e.g., Økland and Bjørnstad, 2006; Gillet, 2008) or agent-host feedbacks (Ager et al., 2007; Seidl et al., 2007). Although less common for abiotic disturbances, which are often primarily modelled as being determined by external forcings, we found examples of dynamic process-based models for all reviewed disturbance agents.

Concepts for the modelling of disturbance events are frequently harnessed in modelling the higher level dynamics of disturbance regimes. Our review corroborated the importance of landscapelevel processes for the mechanistic modelling of disturbance regimes (Fig. 2c). Disturbance interactions, however, which are an important part of the latter, are still predominately modelled using descriptive statistical concepts. This points at particular limitations with regard to our process understanding of complex interactions in disturbance regimes and highlights the need for further research in this area. A prerequisite in this regard, that we hope to foster with this contribution, is to overcome the strongly separated (reductionist) research agendas for individual disturbance agents towards a more holistic (ecosystem-oriented) view of disturbance regimes.

\subsection{Challenges for disturbances modelling under climate change}

Despite the considerable advances since the seminal work of White and Pickett (1985) the modelling of natural disturbances in forest ecosystems - from single events to complex regimes remains challenging. From our review and synthesis of modelling approaches, and under particular consideration of the imminent changes in climate, we propose four major challenges for modelling natural disturbances in forest ecosystems:

(i) Overcoming key limitations in understanding: Despite a considerable research focus on natural disturbances over the last years, we are only gradually developing a comprehensive picture of individual disturbance events, their variability in time and space and the interactions among multiple disturbance events and agents. Unprecedented bark beetle epidemics (Raffa et al., 2008), intricate fire-management interactions (Noss et al., 2006), and widespread drought-induced tree mortality (Allen et al., 2010) highlight areas of yet limited understanding, that are likely to become exacerbated in the face of climate change (Dale et al., 2001). In this regard statistical modelling can provide insights on quantitative relationships for exploratory research questions. For example, structural equation modelling (e.g., Youngblood et al., 2009) or hierarchical Bayesian methods (e.g., McMahon et al., 2009) are particularly suitable for such tasks, allowing the consideration of simultaneous (and interacting) drivers as well as of non-Gaussian, nested and random effects. Furthermore, recent methodological advances have improved our inference abilities in working with the highly variable, incomplete and noisy characteristics of most disturbance datasets (e.g., machine learning algorithms such as random forests, genetic algorithms, and neural networks). Yet, it has to be noted that purely statistical approaches cannot elucidate causalities or make predictions for novel environmental conditions, for which process-based approaches are imperative.

(ii) Improved process modelling: Increased knowledge about quantitative relationships from empirical modelling should stimulate the formulation of process-oriented models. This is of particular importance since a realistic representation of processes in ecological models is likely to enhance their applicability under changing environmental conditions. The growing body of approaches for mechanistic disturbance modelling (Fig. 2b and c) documents the advances made in this field in the recent past (see also Johnson and Miyanishi, 2007). However, a detailed mechanistic representation of disturbance processes in models is still hard to reconcile with the need to embrace the heterogeneity and spatio-temporal dynamics in forest landscapes (cf. the discussion by Gardiner et al., 2008), thus highlighting the need for further development in this field.

(iii) Integrating disturbances into ecosystem models: A consideration of disturbance processes in the context of spatio-temporal forest dynamics is essential, since natural disturbances strongly influence the structure and functioning of forest ecosystems, and, via legacies, have a lasting influence on forest development (Franklin et al., 2002). An important aspect in modelling disturbance regimes is thus to integrate short-term processes of disturbance events with long-term vegetation dynamics. Following Holling et al. (2002), it is this interplay of processes on different temporal and spatial scales that is crucial for the resilience of ecosystems, and ultimately for sustainable development. Our review showed that only a limited set of models addresses this integration of disturbances with dynamic ecosystem processes to date. For example, models of plant physiology offer a consistent framework to study disturbance effects on biogeochemical cycles in forest ecosystems. 

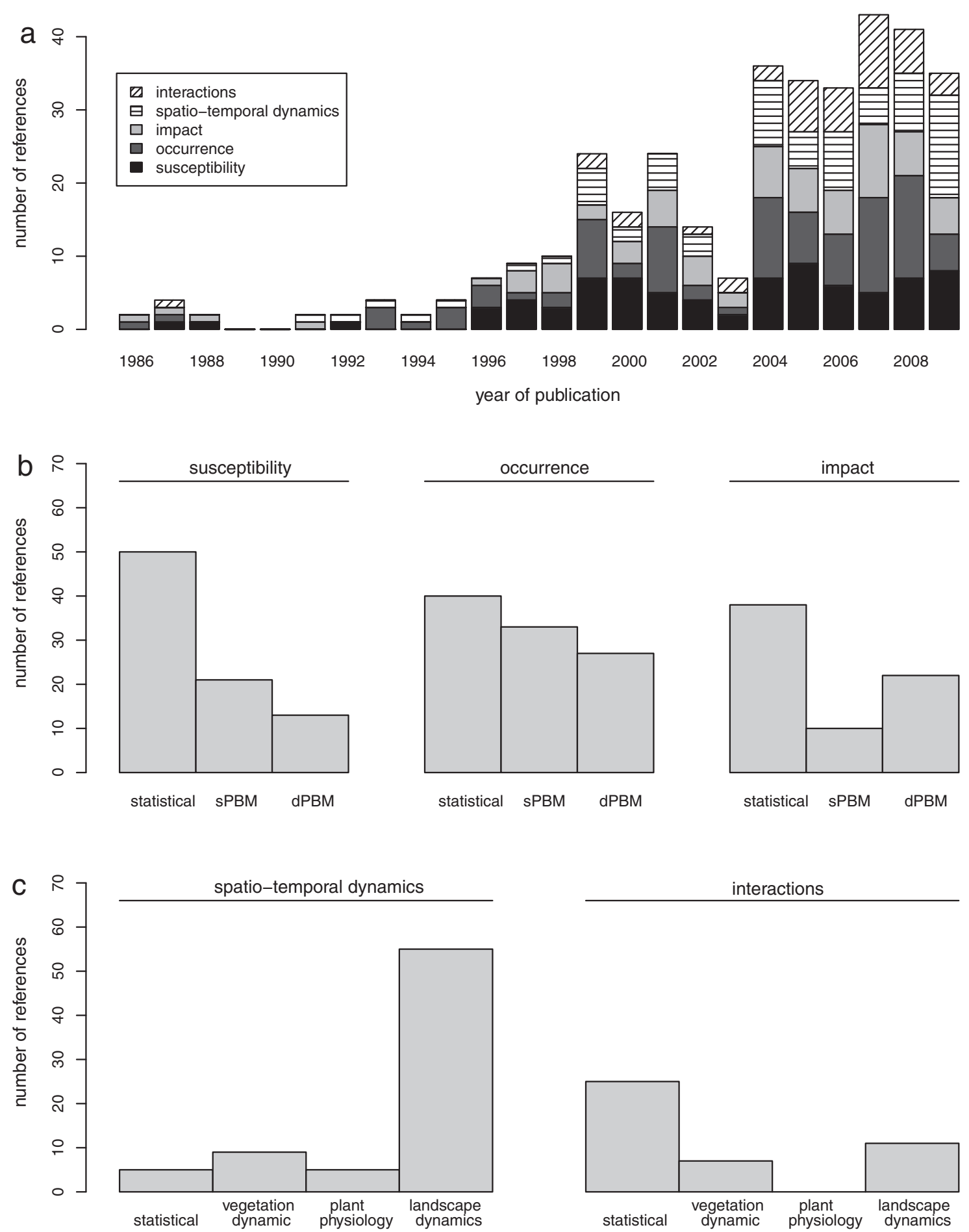

Fig. 2. (a) The emergence of the reviewed disturbance modelling approaches over the last 15 years, grouped by major disturbance mechanisms. Note that the reviewed literature represents a subset of new and innovative approaches for the selected disturbance agents, and is thus only an indicator for the increase of the full body of disturbance modelling literature. See Online Supplement for methodological details. (b) Distribution of general concepts for modelling disturbance events by disturbance mechanism. $\mathrm{sPBM}=$ static process-based models; $\mathrm{dPBM}=$ dynamic process-based models. (c) Distribution of general concepts for modelling disturbance regimes by disturbance mechanism. For a description of disturbance mechanisms and modelling concepts see Tables 1 and 2 respectively.

However, the majority of these approaches lack a detailed representation of forest structure and spatial heterogeneity, and are thus limited with regard to the modelling of disturbance processes (e.g., tree mortality). In this regard concepts from vegetation dynamics have been found to provide a useful platform for integration, since they by design address the major demographic processes growth, mortality and regeneration. (iv) Bringing together scalability and system complexity: A limitation of many vegetation models towards the integration of disturbance regimes is their implicit consideration of space (e.g., the gap model approach, reviewed by Bugmann, 2001). As a rule, disturbances are spatially explicit processes. Concepts from landscape dynamics are focusing explicitly on spatial patterns and interactions, thus offering a valuable platform for 
Table 2

Concepts to model natural disturbances in forest ecosystems.

\begin{tabular}{|c|c|c|}
\hline Level of organization & Concept $^{\mathrm{a}}$ & Characteristics \\
\hline \multirow[t]{3}{*}{ Disturbance event } & Statistical models & $\begin{array}{l}\text { Descriptive modelling; uses empirical data to model response variables by } \\
\text { means of statistical approaches (e.g., uni- and multivariate regression models, } \\
\text { classification and regression trees, distribution-based analyses) }\end{array}$ \\
\hline & Static process-based models & $\begin{array}{l}\text { Mechanistic approaches modelling disturbance processes based on } \\
\text { environmental and vegetation drivers; first-order markovian, i.e. no dynamic } \\
\text { feedbacks (spatial or temporal) and emergent traits within the model system, } \\
\text { (e.g., biophysical disturbance models, bioclimatic envelope models of } \\
\text { biological agents) }\end{array}$ \\
\hline & Dynamic process-based models & $\begin{array}{l}\text { Mechanistic approaches modelling disturbances events as emerging } \\
\text { properties of dynamic (spatial and/or temporal) interactions between } \\
\text { vegetation, environment and disturbance processes (e.g., coupled } \\
\text { vegetation-disturbance models) }\end{array}$ \\
\hline \multirow[t]{4}{*}{ Disturbance regime } & Statistical models & $\begin{array}{l}\text { Descriptive modelling; uses empirical data to model response variables by } \\
\text { means of statistical approaches (e.g., as uni- and multivariate regression } \\
\text { models, classification and regression trees, distribution-based analyses, spatial } \\
\text { statistics approaches) }\end{array}$ \\
\hline & Vegetation dynamics models & $\begin{array}{l}\text { Process-based approaches focusing on spatio-temporal interactions of } \\
\text { disturbances with vegetation structure and composition as emergent } \\
\text { properties of processes such as growth, mortality and reproduction (e.g., gap } \\
\text { models, vegetation state-transition models) }\end{array}$ \\
\hline & Plant physiology model & $\begin{array}{l}\text { Process-based approaches focusing on spatio-temporal interactions of } \\
\text { disturbances with ecosystem functioning (e.g., C and N cycling); processes of } \\
\text { plant physiology such as photosynthesis, respiration and allocation are } \\
\text { modelled explicitly (e.g., models of biogeochemical cycling) }\end{array}$ \\
\hline & Landscape dynamics models & $\begin{array}{l}\text { Process-based approaches focusing on spatio-temporal interactions of } \\
\text { vegetation and disturbances at the landscape scale; modelling of landscape } \\
\text { patterns and processes (e.g., cellular automaton models, pattern generators, } \\
\text { GIS-based models) }\end{array}$ \\
\hline
\end{tabular}

a Although we broadly distinguish statistical and mechanistic concepts, i.e. models for description vs. understanding and prediction, we acknowledge that rather than being mutually exclusive a continuum between those two poles exists (see Korzukhin et al., 1996).

integrative modelling of disturbance-mediated forest dynamics. Yet, the considerable scaling demand in modelling disturbance regimes, i.e. the need to address processes over several levels of organization, remains a considerable challenge in this regard. Many landscape modelling approaches resort to simplified, implicit scaling approaches to address these demands (cf. Bugmann et al., 2000; Mladenoff, 2004). This, however, impairs key capacities of dynamic models with regard to robust projections under novel conditions, such as emergence and adaptive behaviour (Railsback, 2001; Holling and Gunderson, 2002).

Addressing these challenges will foster an integrated, processbased modelling of disturbances, which is needed to support concepts of ecosystem stewardship developed in response to a changing environment (Chapin et al., 2009). We need models that integrate disturbance and vegetation processes, and address their interactions over a wide range of spatial and temporal scales. Towards this goal, the integration of several modelling concepts summarized above appears promising. Potential frameworks for such integration efforts include multi-scale hierarchical approaches assuring consistent and robust scaling (cf. Mäkelä, 2003); modular designs, which allow the incorporation of processes in their respective spatial and temporal domain with interactions facilitated by a common platform (e.g., Scheller et al., 2007); metamodel concepts to consistently scale and integrate process models (e.g., Urban et al., 1999; Seidl et al., 2009); and hybrid approaches integrating multiple concepts towards a balanced representation of a wide variety of ecosystem processes (e.g., Seely et al., 2004).

\subsection{The role of disturbance modelling in ecosystem management}

Disturbances are increasingly recognized as important factors in the stewardship of ecosystems (Jactel et al., 2009; Swanson and Chapin, 2009), and there is no doubt that the growing capacities in disturbance modelling can support forest management on multiple levels. Models allow for a quantitative assessment of disturbance effects on forest resources and can thus demonstrate the consequences of neglecting disturbances in the planning for sustainable forest management (Schelhaas et al., 2002; Seidl et al., 2008). Furthermore, integrated vegetation-disturbance models are essential tools in scenario analysis, allowing management strategies to be scrutinized for their resilience to disturbances (Gunderson, 2000), their trajectories relative to the historic range of variability (Keane et al., 2009), or their vulnerability to climatic changes (Seidl et al., in press). Particularly in pest control and fire management, disturbance models are indispensable tools not only in management planning but also in operational management, e.g., to define burn prescriptions or to coordinate and plan wildfire suppression (e.g., González et al., 2005; Bettinger, 2010).

The stochastic and inherently unpredictable nature of individual disturbance events requires the adoption of probabilistic approaches for addressing them. Disturbance modelling, beyond its immediate utility for forest management, can thus support the transition from a deterministic to a probabilistic framework in management decision making. In many cases stochastic variation due to the effect of individual disturbance events will be orders of magnitude larger than deterministically derived differences between alternative management strategies. Demonstrating such effects by means of integrated vegetation-disturbance models can support a paradigm shift from static optimization of a narrow set of management objectives to managing for complexity with the aim of preserving adaptive capacity as the foundation of sustainable management (Puettmann et al., 2009). The effect of (inherently unpredictable) disturbance events also puts the fallacy of accuracy, often introduced by the application of numerical models in decision support, into perspective (see Wolfslehner and Seidl, in press). Disturbance modelling can thus facilitate a broader perspective of managing under uncertainty in ecosystem stewardship (Ascough et al., 2008). 


\section{Acknowledgements}

This work is a result of working group 2 of the European Union COST action FP0603 "Forest models for research and decision support in sustainable forest management". R. Seidl received support from a Marie Curie Fellowship within the European Community's Seventh Framework Program (grant agreement 237085). A.M. Jönsson acknowledges support from the Mistra Swedish Research Programme for Climate, Impacts and Adaptation, and Grant No. 214-2008-205 to B. Smith from the Swedish Research Council FORMAS. J.R. González-Olabarria received support from the Juan de la Cierva program, Spanish Ministry of Science and Education. Furthermore, the review was supported by the project "Recuperação de áreas ardidas" (financed by IFAP, Portugal), the European Union COST Action FP0701 "Post-fire forest management in southern Europe", and the European Union integrated project MOTIVE "Models for adaptive forest management" (grant No. 226544), co-sponsored by the strategic research programs "Sustainable spatial development of ecosystems, landscapes, seas and regions" and "Climate change" of the Dutch Ministry of Agriculture, Nature Conservation and Food Quality. We thank H. Peltola and two anonymous reviewers for their thoughtful comments on an earlier version of the manuscript.

\section{Appendix A. Supplementary methods and data}

Supplementary methods and data associated with this article can be found, in the online version, at doi:10.1016/j.ecolmodel.2010.09.040.

\section{References}

Abbott, K.C., Dwyer, G., 2007. Food limitation and insect outbreaks: complex dynamics in plant-herbivore models. J. Anim. Ecol. 76, 1004-1014.

Achim, A., Ruel, J.-C., Gardiner, B., 2005. Evaluating the effect of precommercial thinning on the resistance of balsam fir to windthrow through experimentation, modelling and development of simple indices. Can. J. For. Res. 35 1844-1853.

Ager, A.A., McMahan, A., Hayes, J.L., Smith, E.L., 2007. Modelling the effects of thinning on bark beetle impacts and wildfire potential in the Blue Mountains of eastern Oregon. Landsc. Urban Plan. 80, 301-311.

Akashi, N., 2009. Simulation of the effects of deer browsing on forest dynamics. Ecol. Res. 24, 247-255.

Alexander, J.D., Seavy, N.E., Ralph, C.J., Hogoboom, B., 2006. Vegetation and topographical correlates of fire severity from two fires in the Klamath-Siskiyou region of Oregon and California. Int. J. Wildland Fire 15, 237-245.

Allen, C.D., 2007. Interactions across spatial scales among forest dieback, fire, and erosion in Northern New Mexico Landscapes. Ecosystems 10, 797-808.

Allen, C.D., Macalady, A.K., Chenchouni, H., Bachelet, D., McDowell, N., Vennetier, M., Kitzberger, T., Rigling, A., Breshears, D.D., Hogg, E.H., Gonzalez, P., Fensham, R. Zhang, Z., Castro, J., Demidova, N., Lim, J.H., Allard, G., Running, S.W., Semerci, A., Cobb, N., 2010. A global overview of drought and heat-induced tree mortality reveals emerging climate change risks for forests. For. Ecol. Manage. 259, 660-684.

Amatulli, G., Rodrigues, M.J., Trombetti, M., Lovreglio, R., 2006. Assessing long-term fire risk at local scale by means of decision tree technique. J. Geophys. Res. 111 (G04S05), 1-15.

Amiro, B.D., Cantin, A., Flannigan, M.D., de Groot, W.J., 2009. Future emissions from Canadian boreal forest fires. Can. J. For. Res. 39, 383-395.

Ancelin, P., Courbaud, B., Fourcaud, T., 2004. Development of an individual treebased mechanical model to predict wind damage within forest stands. For. Ecol Manage. 203, 101-121.

Anderson, D.G., Catchpole, E.A., DeMestre, N.J., Parkes, T., 1982. Modelling the spread of grass fires. J. Aust. Math. Soc. Ser. B 23, 451-466.

Andrews, P., Bevins, C., Seli, R., 2004. BehavePlus Fire Modeling System, Version 3.0: User's Guide. RMRS-GTR-106. USDA Forest Service, Ogden.

Andrews, P.L., 1986. BEHAVE: Fire Behavior Prediction and Fuel Modelling System. Burn Subsystem. Part 1. Rep. No. GTR INT-194. USDA Forest Service, Intermountain Forest and Range Experiment Station, Ogden, UT.

Araújo, M.B., New, M., 2007. Ensemble forecasting of species distributions. Trends Ecol. Evol. 22, 42-47.

Arroyo, L.A., Pascual, C., Manzanera, J.A., 2008. Fire models and methods to map fuel types: the role of remote sensing. For. Ecol. Manage. 256, 1239-1252.

Ascough II, J.C., Maier, H.R., Ravalico, J.K., Strudley, M.W., 2008. Future research challenges for incorporation of uncertainty in environmental and ecological decision-making. Ecol. Model. 219, 383-399.
Axelson, J.N., Alfaro, R.I., Hawkes, B.C., 2009. Influence of fire and mountain pine beetle on the dynamics of lodgepole pine stands in British Columbia, Canada. For. Ecol. Manage. 257, 1874-1882.

Bachelet, D., Lenihan, J.M., Daly, C., Neilson, R.P., 2000. Interactions between fire, grazing and climate change at Wind Cave National Park, SD. Ecol. Model. 134, 229-244.

Baier, P., 1996. Inference of vigour and host quality of Norway spruce, Picea abies, towards the development of Ips typographus (Coleoptera: Scolytidae). Entomol. Generalis 21, 27-35.

Baier, P., Pennerstorfer, J., Schopf, A., 2007. PHENIPS-a comprehensive phenology model of Ips typographus (L.) (Col., Scolytinae) as a tool for hazard rating of bark beetle infestation. For. Ecol. Manage. 249, 171-186.

Bajocco, S., Ricotta, C., 2008. Evidence of selective burning in Sardinia (Italy): which land-cover classes do wildfires prefer? Landsc. Ecol. 23, 241-248.

Bale, J.S., Masters, G.J., Hodkinson, I.D., Awmack, C., Bezemer, T.M., Brown, V.K., Butterfield, J., Buse, A., Coulson, J.C., Farrar, J., Good, J.E.G., Harrington, R., Hartley, S., Jones, T.H., Lindroth, R.L., Press, M.C., Symrnidoudis, I., Watt, A.D., Whittaker, J.B., 2002. Herbivory in global climate change research: direct effects of rising temperature on insect herbivores. Glob. Change Biol. 8, 1-16.

Band, L.E., Patterson, P., Nemani, R., Running, S.W., 1993. Forest ecosystem processes at the watershed scale: incorporating hillslope hydrology. Agric. For. Met. 63 , 93-126.

Battaglia, M., Sands, P., White, D., Mummery, D., 2004. CABALA: a linked carbon, water and nitrogen model of forest growth for silvicultural decision support. For. Ecol. Manage. 193, 251-282.

Battisti, A., Stastny, M., Netherer, S., Robinet, C., Schopf, A., Roques, A., Larsson, S. 2005. Expansion of geographic range in the pine processionary moth caused by increased winter temperatures. Ecol. Appl. 15, 2084-2096.

Baur, P., Bernath, K., Holthausen, N., Roschewitz, A., 2003. LOTHAR Ökonomische Auswirkungen des Sturms Lothar im Schweizer Wald, Teil I. Einkommensund Vermögenswirkungen für die Waldwirtschaft und gesamtwirtschaftliche Beurteilung des Sturms. Umwelt-Materialien Nr. 157. Bundesamt für Umwelt, Wald und Landschaft, Bern, 190 pp.

Bebi, P., Kulakowski, D., Veblen, T.T., 2003. Interactions between fire and spruce beetles in a subalpine Rocky Mountain forest landscape. Ecology 84, 362-371.

BenDor, T.K., Metcalf, S.S., Fontenot, L.E., Sangunett, B., Hannon, B., 2006. Modelling the spread of the Emerald Ash Borer. Ecol. Model. 197, 221-236.

Bengtsson, A., Nilsson, C., 2007. Extreme value modelling of storm damage in Swedish forests. Nat. Hazards Earth Syst. Sci. 7, 515-521.

Berggren, Å., Björkman, C., Bylund, H., Ayres, M.P., 2009. The distribution and abundance of animal populations in a climate of uncertainty. Oikos 118, 1121-1126.

Berryman, A.A., 1986. Forest Insects. Principles and Practice of Population Management. Plenum Press, New York/London.

Bettinger, P., 2010. An overview of methods for incorporating wildfires into fores planning models. Math. Comput. For. Nat. Res. 2, 43-52.

Beven, K.J., Kirkby, M.J., 1979. A physically based, variable contributing area model of basin hydrology. Hydrol. Sci. 24, 43-69.

Beverly, J.L., Martell, D.L., 2003. Modelling Pinus strobus mortality following prescribed fire in Quetico Provincial Park, northwestern Ontario. Can. J. For. Res. 33 740-751.

Bigler, C., Bugmann, H., 2004. Assessing the performance of theoretical and empirical tree mortality models using tree-ring series of Norway spruce. Ecol. Model. 174, 225-239.

Bigler, C., Kulakowski, D., Veblen, T.T., 2005. Multiple disturbance interactions and drought influence fire severity in Rocky Mountain subalpine forests. Ecology 86, 3018-3029.

Blennow, K., Andersson, M., Sallnäs, O., Olofsson, E., 2010. Climate change and the probability of wind damage in two Swedish forests. For. Ecol. Manage. 259 818-830.

Blennow, K., Olofsson, E., 2008. The probability of wind damage in forestry under a changed wind climate. Clim. Change 87, 347-360.

Blennow, K., Sallnäs, O., 2004. WINDA-a system of models for assessing the probability of wind damage to forest stands within a landscape. Ecol. Model. 175 87-99.

Bogich, T., Shea, K., 2008. A state-dependent model for the optimal management of an invasive metapopulation. Ecol. Appl. 18, 748-761.

Bone, C., Dragicevic, S., Roberts, A., 2007. Evaluating forest management practices using a GIS-based cellular automata modelling approach with multispectral imagery. Environ. Model. Assess. 12, 105-118.

Boose, E.R., Chamberlin, K.E., Foster, D.R., 2001. Landscape and regional impacts of hurricanes in New England. Ecol. Monogr. 71, 27-48.

Bouchard, M., Kneeshaw, D., Bergeron, Y., 2008. Ecosystem management based on large-scale disturbance pulses: a case study from sub-boreal forests of western Quebec (Canada). For. Ecol. Manage. 256, 1734-1742.

Bouchard, M., Pothier, D., 2008. Simulations of the effects of changes in mean fire return intervals on balsam fir abundance, and implications for spruce budworm outbreaks. Ecol. Model. 218, 207-218.

Boulanger, V., Baltzinger, C., Said, S., Ballon, P., Picard, J.F., Dupouey, J.L., 2009. Ranking temperate woody species along a gradient of browsing by deer. For. Ecol. Manage. 258, 1397-1406.

Bova, A.S., Dickinson, M.B., 2005. Linking surface-fire behavior, stem heating, and tissue necrosis. Can. J. For. Res. 35, 814-822.

Breda, N., Huc, R., Granier, A., Dreyer, E., 2006. Temperate forest trees and stands under severe drought: a review of ecophysiological responses, adaptation processes and long-term consequences. Ann. For. Sci. 63, 625-644. 
Breece, C.R., Kolb, T.E., Dickson, B.G., McMillin, J.D., Clancy, K.M., 2008. Prescribed fire effects on bark beetle activity and tree mortality in southwestern ponderosa pine forests. For. Ecol. Manage. 255, 119-128.

Breshears, D.D., Cobb, N.S., Rich, P.M., Price, K.P., Allen, C.D., Balice, R.G., Romme, W.H., Kastens, J.H., Floyd, M.L., Belnap, J., Anderson, J.J., Myers, O.B., Meyer, C.W., 2005. Regional vegetation die-off in response to global-change-type drought. PNAS 102, 15144-15148.

Bugmann, H., 2001. A review of forest gap models. Clim. Change 51, 259-305.

Bugmann, H., Cramer, W., 1998. Improving the behavior of forest gap models along drought gradients. For. Ecol. Model. 103, 247-263.

Bugmann, H., Lindner, M., Lasch, P., Flechsig, M., Ebert, B., Cramer, W., 2000. Scaling issues in forest succession modelling. Clim. Change 44, 265-289.

Bugmann, H.K.M., 1996. A simplified forest model to study species composition along climate gradients. Ecology 77, 2055-2074.

Bugmann, H.K.M., Solomon, A.M., 2000. Explaining forest composition and biomass across multiple biogeographical regions. Ecol. Appl. 10, 95-114.

Bunnell, F.L., Boyland, M., 2003. Decision-support systems: it's the question not the model. J. Nat. Conserv. 10, 269-279.

Byers, J.A., 1993. Simulation and equation models of insect population-control by pheromone-baited traps. J. Chem. Ecol. 19, 1939-1956.

Byers, J.A., 1996. An encounter rate model of bark beetle populations searching at random for susceptible host trees. Ecol. Model. 91, 57-66.

Campbell, E.M., MacLean, D.A., Bergeron, Y., 2008. The severity of budworm-caused growth reductions in Balsam Fir/Spruce stands varies with the hardwood content of surrounding forest landscapes. For. Sci. 54, 195-205.

Canham, C.D., Papaik, M.J., Latty, E.F., 2001. Interspecific variation in susceptibility to windthrow as a function of tree size and storm severity for northern temperate tree species. Can. J. For. Res. 31, 1-10.

Cardille, J.A., Ventura, S.J., Turner, M.G., 2001. Environmental and social factors influencing wildfires in the Upper Midwest, United States. Ecol. Appl. 11, 111-127.

Cary, G., Flannigan, M.D., Keane, R., Bradstock, R., Davies, I., Li, C., Lenihan, J., Logan, K., Parsons, R., 2009. Relative importance of fuel management, ignition management and weather for area burned: evidence from five landscape-fire-succession models. Int. J. Wildland Fire 18, 147-156.

Cary, G.J., Banks, J.C.G., 1999. Fire regime sensitivity to global climate change: an Australian perspective. In: Innes, J.L., Verstraete, M.M., Beniston, M. (Eds.), Advances in Global Change Research. Kluwer Academic Publishers, Dordrecht, pp. 233-246.

Cary, G.J., Keane, R.K., Gardner, R.H., Lavorel, S., Flannigan, M., Davies, I.D., Li, C., Lenihan, J.M., Rupp, T.S., Mouillot, F., 2006. Comparison of the sensitivity of landscape-fire-succession models to variation in terrain, fuel pattern, climate and weather. Landsc. Ecol. 21, 121-137.

Chapin III, F.S., Kofinas, G.P., Folke, C., Carpenter, S.R., Olsson, P., Abel, N., Biggs, R., Naylor, R.L., Pinkerton, E., Smith, D.M.S., Steffen, W., Walker, B., Young, O.R., 2009. Resilience-based stewardship: strategies for navigating sustainable pathways in a changing world. In: Chapin III, F.S., Kofinas, G.P., Folke, C. (Eds.), Principles of Ecosystem Stewardship. Resilience-based Natural Resource Management in a Changing World. Springer, New York, pp. 319-337.

Chiba, Y., 2000. Modelling stem breakage caused by typhoons in plantation Cryptomeria japonica forests. For. Ecol. Manage. 135, 123-131.

Chou, Y.H., Minnich, R.A., Chase, R.A., 1993. Mapping probability of fire occurrence in San Jacinto Mountains, California, USA. Environ. Manage. 17, 129-140.

Christensen, N.L., Bartuska, A.M., Brown, J.H., Carpenter, S., D'antonio, C., Francis, R., Franklin, J.F., MacMahon, J.A., Noss, R.F., Parsons, D.J., Peterson, C.H., Turner, M.G., Woodmansee, R.G., 1996. The report of the Ecological Society of America committee on the scientific basis for ecosystem management. Ecol. Appl. 6, 665-691.

Christiansen, E., Bakke, A., 1988. The spruce bark beetle of Eurasia. In: Berryman, A.A. (Ed.), Dynamics of Forest Insect Populations: Patterns, Causes, Implications. Plenum Publishing Corporation, New York, pp. 479-503.

Chubaty, A.M., Roitberg, B.D., Li, C., 2009. A dynamic host selection model for mountain pine beetle, Dendroctonus ponderosae Hopkins. Ecol. Model. 220, 1241-1250.

Coleman, T.W., Meeker, J.R., Clarke, S.R., Rieske, L.K., 2008. The suppression of Dendroctonus frontalis and subsequent wildfire have an impact on forest stand dynamics. Appl. Veg. Sci. 11, 231-242.

Coops, N.C., Waring, R.H., Law, B.E., 2005. Assessing the past and future distribution and productivity of ponderosa pine in the Pacific Northwest using a process model, 3-PG. Ecol. Model. 183, 107-124.

Coops, N.C., Waring, R.H., Wulder, M.A., White, J.C., 2009. Prediction and assessment of bark beetle-induced mortality of lodgepole pine using estimates of stand vigor derived from remotely sensed data. Remote Sens. Environ. 113, 1058-1066.

Crookston, N.L., Dixon, G.E., 2005. The forest vegetation simulator: a review of its structure, content, and applications. Comp. Electr. Agric. 49, 60-80.

Crookston, N.L., Stage, A.R., 1991. User's Guide to the Parallel Processing Extension of the Prognosis Model. Gen. Tech. Re INT-281. U.S. Department of Agriculture, Forest Service, Intermountain Research Station, Ogden, UT, 88 pp.

Cruz, M.G., Alexander, M.E., Wakimoto, R.H., 2005. Development and testing of models for predicting crown fire rate of spread in conifer forest stands. Can. J. For. Res. 35, 1626-1639.

Cushman, S.A., McKenzie, D., Peterson, D.L., Littell, J., McKelvey, K.S., 2007. Research agenda for integrated landscape modelling. USDA Forest Service - General Technical Report RMRS 194, 50 pp.

Dale, V.H., Joyce, L.A., McNulty, S., Neilson, R.P., Ayres, M.P., Flannigan, M.D., Hanson, P.J., Irland, L.C., Lugo, A.E., Peterson, C.J., Simberloff, D., Swanson, F.J., Stocks,
B.J., Wotton, B.M., 2001. Climate change and forest disturbances. BioScience 51, $723-734$.

Davidson, C.B., Johnson, J.E., Gottschalk, K.W., Amateis, R.L., 2001. Prediction of stand susceptibility and gypsy moth defoliation in Coastal Plain mixed pinehardwoods. Can. J. For. Res. 31, 1914-1921.

de la Riva, J.R., Pérez-Cabello, F., Lana-Renault, N., Koutsias, N., 2004. Mapping forest fire occurrence at a regional scale. Remote Sens. Environ. 92, 363-369.

de Zea Bermudez, P., Mendes, J., Pereira, J.M.C., Turkman, K.F., Vasconcelos, M.J.P., 2009. Spatial and temporal extremes of wildfire sizes in Portugal (1984-2004). Int. J. Wildland Fire 18, 983-991.

Deeming, J.E., Lancaster, J.W., Fosberg, M.A., Furman, R.W., Schroeder, M.J., 1972. The National Fire-Danger Rating System. Rep. No. RM-84. USDA Forest Service, Ogden, UT.

Díaz-Avalos, C., Peterson, D.L., Alvarado, E., Ferguson, S.A., Besag, J.E., 2001. Spacetime modeling of lightning-caused ignitions in the Blue Mountains, Oregon. Can. J. For. Res. 31, 1579-1593.

Díaz-Delgado, R., Lloret, F., Pons, X., 2004. Statistical analysis of fire frequency models for Catalonia (NE Spain, 1975-1998) based on fire scar maps from Landsat MSS data. Int. J. Wildland Fire 13, 89-99.

Doak, P., 2004. The impact of tree and stand characteristics on spruce beetle (Coleoptera: Scolytidae) induced mortality of white spruce in the Copper River Basin, Alaska. Can. J. For. Res. 34, 810-816.

Dobbertin, M., 2002. Influence of stand structure and site factors on wind damage comparing the storms Vivian and Lothar. For. Snow Landsc. Res. 77, 187-205.

Dolezal, P., Sehnal, F., 2007. Effects of photoperiod and temperature on the development and diapause of the bark beetle Ips typographus. J. Appl. Entomol. 131, 165-173.

Dukes, J.S., Pontius, J., Orwig, D., Garnas, J.R., Rodgers, V.L., Brazee, N., Cooke, B., Theoharides, K.A., Stange, E.E., Harrington, R., Ehrenfeld, J., Gurevitch, J., Lerdau, M., Stinson, K., Wick, R., Ayres, M., 2009. Responses of insect pests, pathogens, and invasive plant species to climate change in the forests of northeastern North America: What can we predict? Can. J. For. Res. 39, 231-248.

Dungan, R.J., Turnbull, M.H., Kelly, D., 2007. The carbon costs for host trees of a phloem-feeding herbivore. J. Ecol. 95, 603-613.

Dupuy, L.X., Fourcaud, T., Lac, P., Stokes, A., 2007. A generic 3D finite element model of tree anchorage integrating soil mechanics and real root system architecture. Am. J. Bot. 94, 1506-1514.

Dutilleul, P., Nef, L., Frigon, D., 2000. Assessment of site characteristics as predictors of the vulnerability of Norway spruce (Picea abies Karst.) stands to attack by Ips typographus L. (Col., Scolytidae). J. Appl. Entomol. 124, 1-5.

Edgar, C.B., Burk, T.E., 2007. Demonstration and verification of a model that generates defoliation patterns in forested landscapes. Ecol. Model. 205, 301-313.

Eisenbies, M.H., Davidson, C., Johnson, J., Amateis, R., Gottschalk, K., 2007. Tree mortality in mixed pine - hardwood stands defoliated by the European gypsy moth (Lymantria dispar L.). For. Sci. 53, 683-691.

Engel, V.C., Stieglitz, M., Williams, M., Griffin, K.L., 2002. Forest canopy hydraulic properties and catchment water balance: observations and modelling. Ecol. Model. 154, 263-288.

Eriksson, M., Pouttu, A., Roininen, H., 2005. The influence of windthrow area and timber characteristics on colonization of wind-felled spruces by Ips typographus (L.). For. Ecol. Manage. 216, 105-116.

Eschtruth, A.K., Battles, J.J., 2008. Deer herbivory alters forest response to canopy decline caused by an exotic insect pest. Ecol. Appl. 18, 360-376.

Fabrika, M., Vaculčiak, T., 2009. Modelling natural disturbances in tree growth model SIBYLA. In: Střelcová, K., Matyas, C., Kleidon, A., Lapin, M., Matejka, F., Blaženec, M., Škvarenina, J., Holécy, J. (Eds.), Bioclimatology and Natural Hazards. Springer, pp. 155-164.

Faccoli, M., Stergulc, F., 2004. Ips typographus (L.) pheromone trapping in south Alps: spring catches determine damage thresholds. J. Appl. Entomol. 128, 307-311.

Faccoli, M., Stergulc, F., 2006. A practical method for predicting the short-time trend of bivoltine populations of Ips typographus (L.) (Col., Scolytidae). J. Appl. Entomol. 130, 61-66.

Fajvan, M.A., Rentch, J., Gottschalk, K., 2008. The effects of thinning and gypsy moth defoliation on wood volume growth in oaks. Trees 22, 257-268.

Falk, D.A., Miller, C.M., McKenzie, D., Black, A.E., 2007. Crossscale analysis of fire regimes. Ecosystems 10, 809-826.

Fernandes, P.M., Botelho, H.S., Rego, F.C., Loureiro, C., 2009. Empirical modelling of surface fire behaviour in maritime pine stands. Int J. Wildland Fire 18,698-710.

Fernandes, P.M., Vega, J.A., Jiménez, E., Rigolot, E., 2008. Fire resistance of European pines. For. Ecol. Manage. 256, 246-255.

Fettig, C.J., Klepzig, K.D., Billings, R.F., Munson, A.S., Nebeker, T.E., Negrón, J.F., Nowak, J.T., 2007. The effectiveness of vegetation management practices for prevention and control of bark beetle infestations in coniferous forests of the western and southern United States. For. Ecol. Manage. 238, 24-53.

Finney, M.A., 1998. FARSITE: Fire Area Simulator-model Development and Valuation. Rep. No. Paper RMRS-RP-4. USDA Forest Service, Ogden, UT.

Finney, M.A., Seli, R.C., McHugh, C.H., Ager, A.A., Bahro, B., Agee, J.K., 2007. Simulation of long-term landscape-level fuel treatment effects on large wildfires. Int. J. Wildland Fire 16, 712-727.

Fischlin, A., Bugmann, H., Gyalistras, D., 1995. Sensitivity of a forest ecosystem model to climate parametrization schemes. Environ. Pollut. 87, 267-282.

Fleming, R.D., Candau, J.N., McAlpine, R.S., 2002. Landscape-scale analysis of interactions between insect defoliation and forest fire in central Canada. Clim. Change 55, 251-272. 
Fonseca, T.F., 2004. Modelação do crescimento, mortalidade e distribuição diamétrica, do pinhal bravo no Vale do Tâmega. PhD Thesis. Vila Real, UTAD Portugal, 248.

Forestry Canada, 1992. Development and Structure of the Canadian Forest Fire Behavior Prediction System. Rep. No. ST-X-3. Forestry Canada, Ottawa.

Forman, R.T.T., 1995. Land Mosaics: The Ecology of Landscapes and Regions. Cambridge University Press, 656 pp.

Franklin, J.F., Spies, T.A., Pelt, R.V., Carey, A.B., Thornburgh, D.A., Berg, D.R., Lindenmayer, D.B., Harmon, M.E., Keeton, W.S., Shaw, D.C., Bible, K., Chen, J., 2002. Disturbances and structural development of natural forest ecosystems with silvicultural implications, using Douglas-fir forests as an example. For. Ecol. Manage. 155, 399-423.

Frelich, L.E., Lorimer, C.G., 1991. A simulation of landscape-level stand dynamics in the northern hardwood region. J. Ecol. 79, 223-233.

Friend, A.D., Stevens, A.K., Knox, R.G., Cannell, M.G.R., 1997. A process-based, terrestrial biosphere model of ecosystem dynamics (Hybrid v3.0). Ecol. Model. 95, 249-287.

Führer, E., Nopp, U., 2001. Ursachen, Vorbeugung und Sanierung von Waldschäden. Facultas, Vienna, Austria.

Fujita, T.T., 1987. U.S. Tornadoes: Part One, 70-year Statistics. Satellite and Mesometeorology Research Project Research Paper 218. University of Chicago, Chicago IL, USA.

Gan, J.B., 2004. Risk and damage of southern pine beetle outbreaks under global climate change. For. Ecol. Manage. 191, 61-71.

Gardiner, B., Byrne, K., Hale, S., Kaminura, K., Mitchell, S.J., Peltola, H., Ruel, J.C., 2008 A review of mechanistic modelling of wind damage risk to forests. Forestry 81 447-463.

Gardiner, B., Peltola, H., Kellomäki, S., 2000. Comparison of two models for predicting the critical wind speeds required to damage coniferous trees. Ecol. Model. 129, 1-23.

Gardiner, B.A., Quine, C.P., 2000. Management of forests to reduce the risk of abiotic damage-a review with particular reference to the effect of strong winds. For. Ecol. Manage. 135, 261-277.

Gaylord, M.L., Williams, K.K., Hofstetter, R.W., McMillin, J.D., Degomez, T.E., Wagner M.R., 2008. Influence of temperature on spring flight initiation for southwestern ponderosa pine bark beetles (Coleoptera: Curculionidae, Scolytinae). Environ. Entomol. 37, 57-69.

Gillet, F., 2008. Modelling vegetation dynamics in heterogeneous pasture-woodland landscapes. Ecol. Model. 217, 1-18.

Gillet, F., Besson, O., Gobat, J.M., 2002. PATUMOD: a compartment model of vegetation dynamics in wooded pastures. Ecol. Model. 147, 267-290.

Gimmi, U., Wolf, A., Bürgi, M., Scherstjanoi, M., Bugmann, H., 2009. Quantifying disturbance effects on vegetation carbon pools in mountain forests based on historical data. Reg. Environ. Change 9, 121-130.

Girardin, M.P., Mudelsee, M., 2008. Past and future changes in Canadian boreal wildfire activity. Ecol. Appl. 18, 391-406.

González, J.R., Palahí, M., Pukkala, T., 2005. Integrating fire risk considerations in forest management planning in Spain-a landscape level perspective. Landsc. Ecol. 20, 957-970

González-Olabarria, J.R., Mola, B., Pukkala, T., Palahí, M., 2010. Using multi-scale spatial analysis to assess fire ignition density in Catalonia, Spain. Manuscript.

Grant, R.F., Zhang, Y., Yuan, F., Wang, S., Hanson, P.., Gaumont-Guay, D., Chen, J. Black, T.A., Barr, A., Baldocchi, D.D., Arain, A., 2006. Intercomparison of techniques to model water stress effects on $\mathrm{CO}_{2}$ and energy exchange in temperate and boreal deciduous forests. Ecol. Model. 196, 289-312.

Gray, D.R., 2004. The gypsy moth life stage model: landscape-wide estimates of gypsy moth establishment using a multi-generational phenology model. Ecol. Model. 176, 155-171.

Gray, D.R., 2008. The relationship between climate and outbreak characteristics of the spruce budworm in eastern Canada. Clim. Change 87, 361-383.

Gray, D.R., Ravlin, F.W., Braine, J.A., 2001. Diapause in the gypsy moth: a model of inhibition and development. J. Insect Phys. 47, 173-184.

Gray, D.R., Régnière, J., Boulet, B., 2000. Analysis and use of historical patterns of spruce budworm defoliation to forecast outbreak patterns in Quebec. For. Ecol. Manage. 127, 217-231.

Grime, J.P., 2001. Plant Strategies, Vegetation Processes, and Ecosystem Properties, 2nd ed. Wiley, Chichester, $417 \mathrm{pp}$

Grote, R., Pretzsch, H., 2002. A model for individual tree development based on physiological processes. Plant Biol. 4, 167-180.

Gunderson, L.H., 2000. Ecological resilience-in theory and applications. Ann. Rev. Ecol. Syst. 31, 425-439.

Gutschick, V.P., Bassirirad, H., 2003. Extreme events as shaping physiology, ecology and evolution of plants: towards a unified definition and evaluation of their consequences. New Phytol. 160, 21-42.

Hall, S.A., Burke, I.C., Hobbs, N.T., 2006. Litter and dead wood dynamics in ponderosa pine forests along a 160-year chronosequence. Ecol. Appl. 16, 2344-2355.

Hanewinkel, M., Zhou, W., Schill, C., 2004. A neural network approach to identify forest stands susceptible to wind damage. For. Ecol. Manage. 196, 227-243.

Hanson, P.J., Amthor, J.S., Wullschleger, S.D., Wilson, K.B., Grant, R.F., Hartley, A., Hui, D., Hunt, E.R., Johnson, D.W., Kimball, J.S., King, A.W., Luo, Y., McNulty, S.G. Sun, G., Thornton, P.E., Wang, S., Williams, M., Baldocchi, D.D., Cushman, R.M. 2004. Oak forest carbon and water simulations: model intercomparisons and evaluations against independent data. Ecol. Monogr. 74, 443-489.

Hawkes, B., Taylor, S., Stockdale, C., Shore, T., Beukema, S., Robinson, D., 2005. Pre dicting Mountain Pine Beetle impacts on Lodgepole Pine stands and woody debris characteristics in a mixed severity fire regime using PrognosisBC and the fire and fuels extension. In: Mountain Pine Beetle Initiative Working Paper 2005-22. Natural Resources Canada, Canadian Forest Service, Victoria, Canada, $17 \mathrm{pp}$.

He, H.S., Mladenoff, D.J., Boeder, J., 1999. An object-oriented forest landscape model and its representation of tree species. Ecol. Model. 119, 1-19.

He, H.S., Mladenoff, D.J., 1999. Spatially explicit and stochastic simulation of forest landscape fire disturbance and succession. Ecology 80, 81-99.

Heikkinen, R.K., Luoto, M., Araújo, M.B., Virkkala, R., Thuiller, W., Sykes, M.T., 2006. Methods and uncertainties in bioclimatic envelope modelling under climate change. Prog. Phys. Geogr. 30, 751-777.

Hemstrom, M.A., Merzenich, J., Reger, A., Wales, B., 2007. Integrated analysis of landscape management scenarios using state and transition models in the uppe Grande Ronde River Subbasin, Oregon, USA. Landsc. Urban Plan. 80, 198-211.

Hickler, T., Smith, B., Sykes, M.T., Davis, M.B., Sugita, S., Walker, K., 2004. Using a generalized vegetation model to simulate vegetation dynamics in northeastern USA. Ecology 85, 519-530.

Hogg, E.H., 1999. Simulation of interannual responses of trembling aspen stands to climatic variation and insect defoliation in western Canada. Ecol. Model. 114, 175-193.

Holling, C.S., Gunderson, L.H., 2002. Resilience and adaptive cycles. In: Gunderson, L.H., Holling, C.S. (Eds.), Panarchy: Understanding Transformations in Human and Natural Systems. Island Press, Washington, DC, pp. 25-62.

Holling, C.S., Gunderson, L.H., Peterson, G.D., 2002. Sustainability and panarchies. In: Gunderson, L.H., Holling, C.S. (Eds.), Panarchy: Understanding Transformations in Human and Natural Systems. Island Press, Washington, DC, pp. 63-102.

Hood, S., Bentz, B., 2007. Predicting postfire Douglas-fir beetle attacks and tree mortality in the northern Rocky Mountains. Can. J. For. Res. 37, 1058-1069.

Jactel, H., Nicoll, B.C., Branco, M., Gonzalez-Olabarria, J.R., Grodzki, W., Langström, B., Moreira, F., Netherer, S., Orazio, C., Piou, D., Santos, H., Schelhaas, M.J., Tojic, K., Vodde, F., 2009. The influences of forest stand management on biotic and abiotic risks of damage. Ann. For. Sci. 66 (701), 1-18.

Jalkanen, A., Mattila, U., 2000. Logistic regression models for wind and snow damage in northern Finland based on the National Forest Inventory data. For. Ecol. Manage. 135, 315-330.

James, K.R., Haritos, N., Ades, P.K., 2006. Mechanical stability of trees under dynamic loads. Am. J. Bot. 93, 1522-1530.

Jarvis, C.H., 2001. GEOFBUG: a geographical modelling environment for assessing the likelihood of pest development. Environ. Model. Software 16, 753-765.

Jenkins, M.J., Hebertson, E., Page, W., Jorgensen, C.A., 2008. Bark beetles, fuels, fires and implications for forest management in the Intermountain West. For. Ecol. Manage. 254, 16-34.

Johnson, E.A., Miyanishi, K., 2007. Disturbance and succession. In: Johnson, E.A. Miyanishi, K. (Eds.), Plant Disturbance Ecology. The Process and the Response. Elsevier, Amsterdam, pp. 1-14.

Jönsson, A.M., Appelberg, G., Harding, S., Bärring, L., 2009. Spatio-temporal impact of climate change on the activity and voltinism of the spruce bark beetle, Ips typographus. Glob. Change Biol. 15, 486-499.

Jönsson, A.M., Harding, S., Bärring, L., Ravn, H.P., 2007. Impact of climate change on the population dynamics of Ips typographus in southern Sweden. Agric. For. Met. $146,70-81$.

Jorritsma, I.T.M., van Hees, A.F.M., Mohren, G.M.J., 1999. Forest development in relation to ungulate grazing: a modelling approach. For. Ecol. Manage. 120, $23-34$.

Keane, R.E., Austin, M., Field, C., Huth, A., Lexer, M.J., Peters, D., Solomon, A., Wyckoff, P., 2001. Tree mortality in gap models: application to climate change. Clim. Change 50,509-540.

Keane, R.E., Cary, G.J., Davies, I.D., Flannigan, M.D., Gardner, R.H., Lavorel, S., Lenihan, J.M., Li, C., Rupp, T.S., 2004. A classification of landscape fire succession models: spatial simulations of fire and vegetation dynamics. Ecol. Model. 179, 3-27.

Keane, R.E., Cary, G.J., Parsons, R., 2003. Using simulation to map fire regimes: an evaluation of approaches, strategies, and limitations. Int. J. Wildland Fire 12, 309-322.

Keane, R.E., Drury, S.A., Karau, E.C., Hessburg, P.F., Reynolds, K.M., 2010. A method for mapping fire hazard and risk across multiple scales and its application in fire management. Ecol. Model. 221, 2-18.

Keane, R.E., Hessburg, P.F., Landres, P.B., Swanson, F.J., 2009. The use of historica range and variability (HRV) in landscape management. For. Ecol. Manage. 258 $1025-1037$

Keane, R.E., Ryan, K.C., Running, S.W., 1996. Simulating effects of fire on northern Rocky Mountain landscapes with the ecological process model FIRE-BGC. Tree Phys. 16, 319-331.

Keeley, J.E., 2009. Fire intensity, fire severity and burn severity: a brief review and suggested usage. Int. J. Wildland Fire 18, 116-126.

Kerzenmacher, T., Gardiner, B., 1998. A mathematical model to describe the dynamic response of a spruce tree to the wind. Trees 12, 385-394.

King, K.J., Bradstock, R.A., Cary, G.J., Chapman, J., Marsden-Smedley, J.B., 2008. The relative importance of fine-scale fuel mosaics on reducing fire risk in south-west Tasmania, Australia. Int. J. Wildland Fire 17, 421-430.

Kirby, K.J., 2004. A model of a natural wooded landscape in Britain as influenced by large herbivore activity. Forestry 77, 405-420.

Kloster, S., Mahowald, N.M., Randerson, J.T., Thornton, P.E., Hoffman, F.M., Levis, S., Lawrence, P.J., Feddema, J.J., Oleson, K.W., Lawrence, D.M., 2010. Fire dynamics during the 20th century simulated by the Community Land Model. Biogeosciences 7, 1877-1902.

Kobziar, L., Moghaddas, J., Stephens, S.L., 2006. Tree mortality patterns following prescribed fires in a mixed conifer forest. Can. J. For. Res. 36, 3222-3238. 
Kohm, K.A., Franklin, J.F., 1997. Creating a Forestry for the 21st Century. The Science of Ecosystem Management. Island Press, Washington, DC, 475 pp.

Komonen, A., Kouki, J., 2008. Do restoration fellings in protected forests increase the risk of bark beetle damages in adjacent forests? A case study from Fennoscandian boreal forest. For. Ecol. Manage. 255, 3736-3743.

Korzukhin, M.D., Ter-Mikaelian, M.T., Wagner, R.G., 1996. Process versus empirical models: which approach for forest ecosystem management? Can. J. For. Res. 26, 879-887.

Kourtz, P., Nozaki, S., O'Regan, W., 1977. Forest fires in the computer: a model to predict the perimeter location of a forest fire. Fish. Environ. Can., Can. For. Serv., For. Fire Res. Inst., Ottawa, On., 26 (Inf. Rep. FF-X-65).

Kramer, K., Groen, T.A., van Wieren, S.E., 2003. The interacting effects of ungulates and fire on forest dynamics: an analysis using the model FORSPACE. For. Ecol. Manage. 181, 205-222.

Kramer, K., Groot Bruinderink, G.W.T.A., Prins, H.H.T., 2006. Spatial interactions between ungulate herbivory and forest management. For. Ecol. Manage. 226, 238-247.

Kramer, M.G., Hansen, A.J., Taper, M.L., Kissinger, E.J., 2001. Abiotic controls on longterm windthrow disturbance and temperate rain forest dynamics in southeast Alaska. Ecology 82, 2749-2768.

Krivtsov, V., Vigy, O., Legg, C., Curt, T., Rigolot, E., Lecomte, I., Jappiot, M., LampinMaillet, C., Fernandes, P., Pezzatti, G.B., 2009. Fuel modelling in terrestrial ecosystems: an overview in the context of the development of an objectorientated database for wild fire analysis. Ecol. Model. 220, 2915-2926.

Kulakowski, D., Veblen, T.T., 2007. Effect of prior disturbances on the extent and severity of wildfire in Colorado subalpine forests. Ecology 88, 759-769.

Kupfer, J.A., Myers, A.T., McLane, S.E., Melton, G., 2008. Patterns of forest damage in a southern Mississippi landscape caused by hurricane Katrina. Ecosystems 11, 45-60.

Kurz, W.A., Apps, M.J., 1999. A 70-year retrospective analysis of carbon fluxes in the Canadian forest sector. Ecol. Appl. 9, 526-547.

Kurz, W.A., Apps, M.J., Webb, T.M., McNamee, P.J., 1992. Carbon Budget of the Canadian Forest Sector. Phase I. Forestry Canada. Northern Forestry Centre, Edmonton (Inf. Rep. NOR-X-326).

Kurz, W.A., Beukema, S.J., Klenner, W., Greenough, J.A., Robinson, D.C.E., Sharpe, A.D., Webb, T.M., 2000. TELSA: the tool for exploratory landscape scenario analyses. Comp. Electr. Agric. 27, 227-242.

Kurz, W.A., Dymond, C.C., White, T.M., Stinson, G., Shaw, C.H., Rampley, G.J., Smyth, C., Simpson, B.N., Neilson, E.T., Troymow, J.A., Metsaranta, J., Apps, M.J., 2009. CBM-CFS3: a model of carbon-dynamics in forestry and land-use change implementing IPCC standards. Ecol. Model. 220, 480-504.

LaCroix, J.J., Quiglin, L., Chen, J., 2008. Edge effects on fire spread in a disturbed Northern Wisconsin landscape. Landsc. Ecol. 23, 1081-1092.

Lanquaye-Opoku, N., Mitchell, S.J., 2005. Portability of stand-level empirical windthrow risk models. For. Ecol. Manage. 216, 134-148.

Larsson, S., Ekbom, B., Björkman, C., 2000. Influence of plant quality on pine sawfly population dynamics. Oikos $89,440-450$.

Lasch, P., Badeck, F.W., Suckow, F., Lindner, M., Mohr, P., 2005. Model-based analysis of management alternatives at stand and regional level in Brandenburg (Germany). For. Ecol. Manage. 207, 59-74.

Lee, S.D., Park, S., Park, Y.S., Chung, Y.J., Lee, B.Y., Chon, T.S., 2007. Range expansion of forest pest populations by using the lattice model. Ecol. Model. 203,157-166.

Lee, S.-W., Lee, M.-B., Lee, Y.-G., Won, M.-S., Kim, J.-J., Hong, S.-K., 2009. Relationship between landscape structure and burn severity at the landscape and class levels in Samchuck, South Korea. For. Ecol. Manage. 258, 1594-1604.

Lexer, M.J., Hönninger, K., 1998. Simulated effects of bark beetle infestations on stand dynamics in Picea abies stands: coupling a patch model and a stand risk model. In: Beniston, M., Innes, J.L. (Eds.), The Impacts of Climate Variability on Forests. Springer, Berlin, pp. 288-308.

Lexer, M.J., Hönninger, K., 2001. A modified 3D-patch model for spatially explicit simulation of vegetation composition in heterogeneous landscapes. For. Ecol. Manage. 144, 43-65.

Li, C., Barclay, H.J., 2001. Fire disturbance patterns and forest age structure. Nat. Resour. Model. 14, 495-521

Li, C., Barclay, H.J., Hawkes, B.C., Taylor, S.W., 2005. Lodgepole pine forest age class dynamics and susceptibility to mountain pine beetle attack. Ecol. Complex. 2, 232-239.

Li, C., Hans, H., Barclay, H., Liu, J., Carlson, G., Campbell, D., 2008. Comparison of spatially explicit forest landscape fire disturbance models. For. Ecol. Manage. $254,499-510$

Li, C., Termikaelian, M., Perera, A., 1997. Temporal fire disturbance patterns on a forest landscape. Ecol. Model. 99, 137-150.

Lindemann, J.D., Baker, W.L., 2002. Using GIS to analyse a severe forest blowdown in the Southern Rocky Mountains. Int. J. Geograph. Inform. Sci. 16, 377399.

Lindner, M., Maroschek, M., Netherer, S., Kremer, A., Barbati, A., Garcia-Gonzalo, J., Seidl, R., Delzon, S., Corona, P., Kolström, M., Lexer, M.J., Marchetti, M., 2010. Climate change impacts, adaptive capacity, and vulnerability of European forest ecosystems. For. Ecol. Manage. 259, 698-709.

Lindroth, A., Lagergren, F., Grelle, A., Klemedtsson, L., Langvall, O., Weslien, P., Tuulik, J., 2009. Storms can cause Europe-wide reduction in forest carbon sink. Glob. Change Biol. 15, 346-355.

Lloret, F., Calvo, E., Pons, X., Díaz-Delgado, R., 2002. Wildfires and landscape patterns in the Eastern Iberian Peninsula. Landsc. Ecol. 17, 745-759.

Loboda, T.V., Csiszar, I.A., 2007. Assessing the risk of ignition in the Russian far east within a modelling framework of fire threat. Ecol. Appl. 17, 791-805.
Logan, J.A., Bentz, B.J., 1999. Model analysis of mountain pine beetle (Coleoptera: Scolytidae) seasonality. Environ. Entomol. 28, 924-934.

Logan, J.A., White, P., Bentz, B., Powell, J.A., 1998. Model analysis of spatial patterns in mountain pine beetle outbreaks. Theor. Popul. Biol. 53, 236-255.

Lohmander, P., Helles, F., 1987. Windthrow probability as a function of stand characteristics and shelter. Scand. J. For. Res. 2, 227-238.

Long, J.N., 2009. Emulating natural disturbance regimes as a basis for forest management: a North American view. For. Ecol. Manage. 257, 1868-1873.

Lundquist, J.E., 2007. The relative influence of diseases and other small-scale disturbances on fuel loading in the Black Hills. Plant Dis. 91, 147-152.

Luther, J.E., Franklin, S.E., Hudak, J., Meades, J., 1997. Forecasting the susceptibility and vulnerability of Balsam fir stands to insect defoliation with Landsat Thematic Mapper data. Remote Sens. Environ. 59, 77-91.

Lynch, H.J., Renkin, R.A., Crabtree, R.L., Moorcroft, P.R., 2006. The influence of previous mountain pine beetle (Dendroctonus ponderosae) activity on the 1988 Yellowstone Fires. Ecosystems 9, 1318-1327.

Magnussen, S., Boudewyn, P., Alfaro, R., 2004. Spatial prediction of the onset of spruce budworm defoliation. For. Chron. 80, 485-494.

Mäkelä, A., 2003. Process-based modelling of tree and strand growth: towards a hierarchical treatment of multiscale processes. Can. J. For. Res. 33, 398-409.

Malamud, B.D., Millington, J.D.A., Perry, G.L.W., 2005. Characterizing wildfire regimes in the United States. PNAS 102, 4694-4699.

Malmström, C.M., Raffa, K.F., 2000. Biotic disturbance agents in the boreal forest: considerations for vegetation change models. Glob. Change Biol. 6, 35-48.

Martell, D.L., Otukol, S., Stocks, B.J., 1987. A logistic model for predicting daily peoplecaused forest fire occurrence in Ontario. Can. J. For. Res. 17, 394-401.

Martinez, J., Vega-Garcia, C., Chuvieco, E., 2009. Human-caused wildfire risk rating for prevention planning in Spain. J. Environ. Manage. 90, 1241-1252.

Martinez-Vilalta, J., Pinol, J., Beven, K., 2002. A hydraulic model to predict droughtinduced mortality in woody plants: an application to climate change in the Mediterranean. Ecol. Model. 155, 127-147.

Mason, R.R., Wickman, B.E., Paul, H.G., 1997. Radial growth response of Douglas-fir and grand fir to larval densities of the Douglas-fir Tussock Moth and the Western Spruce Budworm. For. Sci. 43, 194-205.

Massei, G., Hartley, S.E., Bacon, P.J., 2000. Chemical and morphological variation of Mediterranean woody evergreen species: do plants respond to ungulate browsing? J. Veg. Sci. 11, 1-8.

Mayer, P., Brang, P., Dobbertin, M., Hallenbarter, D., Renaud, J.P., Walthert, L., Zimmermann, S., 2005. Forest storm damage is more frequent on acidic soils. Ann. For. Sci. 62, 303-311.

McDowell, N., Pockman, W.T., Allen, C.D., Breshears, D.D., Cobb, N., Kolb, T., Plaut, J., Sperry, J., West, A., Williams, D.G., Yepez, E.A., 2008. Mechanisms of plant survival and mortality during drought: why do some plants survive while others succumb to drought? New Phytologist 178, 719-739.

McHugh, C., Kolb, T.E., 2003. Ponderosa pine mortality following fire in northern Arizona. Int. J. Wildland Fire 12, 7-22.

McMahon, S.M., Dietze, M.C., Hersh, M.H., Moran, E.V., Clark, J.S., 2009. A predictive framework to understand forest responses to global change. Ann. N. Y. Acad. Sci. $1162,221-236$

Mermoz, M., Kitzberger, T., Veblen, T.T., 2005. Landscape influences on occurrence and spread of wildfires in Patagonian forests and shrublands. Ecology 86, 2705-2715.

Michaletz, S.T., Johnson, E.A., 2006. A heat transfer model of crown scorch in forest fires. Can. J. For. Res. 36, 2839-2851.

Michaletz, S.T., Johnson, E.A., 2007. How forest fires kill trees: a review of the fundamental biophysical processes. Scand. J. For. Res. 22, 500-515.

Miller, C., Urban, D.L., 1999. A model of surface fire, climate, and forest pattern in the Sierra Nevada, California. Ecol. Model. 114, 113-135.

Mills, N.J., Getz, W.M., 1996. Modelling the biological control of insect pests: a review of host-parasitoid models. Ecol. Model. 92, 121-143.

Mitchell, S.J., 1998. A diagnostic framework for windthrow risk estimation. For. Chron. 74, 100-105.

Mitchell, S.J., Hailemariam, T., Kulis, Y., 2001. Empirical modelling of cutblock edge windthrow risk on Vancouver Island, Canada, using stand level information. For. Ecol. Manage. 154, 117-130.

Mitchell, S.J., Lanquaye-Opoku, N., Modzelewski, H., Shen, Y., Stull, R., Jackson, P., Murphy, B., Ruel, J.C., 2008. Comparison of wind speeds obtained using numerical weather prediction models and topographic exposure indices for predicting windthrow in mountainous terrain. For. Ecol. Manage. 254, 193-204.

Mitikka, V., Heikkinen, R.K., Luoto, M., Araújo, M.B., Saarinen, K., Pöyry, J., Fronzek, S., 2008. Predicting range expansion of the map butterfly in Northern Europe using bioclimatic models. Biodiv. Conserv. 17, 623-641.

Mladenoff, D.J., 2004. LANDIS and forest landscape models. Ecol. Model. 180, 7-19.

Mladenoff, D.J., He, H.S., 1999. Design, behavior and application of LANDIS, an object-oriented model of forest landscape disturbance and succession. In: Mladenoff, D.J., Baker, W.L. (Eds.), Spatial Modelling of Forest Landscape Change: Approaches and Applications. Cambridge University Press, Cambridge, UK, pp. 125-162.

Moloney, K.A., Levin, S.A., 1996. The effects of disturbance architecture on landscapelevel population dynamics. Ecology 77, 375-394.

Moorcroft, P.R., Hurtt, G.C., Pacala, S.W., 2001. A method for scaling vegetation dynamics: the ecosystem demography model (ED). Ecol. Monogr. 71, 557-586.

Moreira, F., Rego, F.C., Ferreira, P.G., 2001. Temporal (1958-1995) pattern of change in a cultural landscape of northwestern Portugal: implications for fire occurrence. Landsc. Ecol. 16, 557-567. 
Moreira, F., Vaz, P., Catry, F., Silva, J.S., 2009. Regional variations in wildfire susceptibility of land-cover types in Portugal: implications for landscape management to minimize fire hazard. Int. J. Wildland Fire 18, 563-574.

Moritz, M.A., Keeley, J.E., Johnson, E.A., Schaffner, A.A., 2004. Testing a basic assumption of shrubland fire management: how important is fuel age? Front. Ecol. Environ. 2, 67-72.

Moritz, M.A., 1997. Analyzing extreme disturbance events: fire in Los Padres National Forest. Ecol. Appl. 7, 1252-1262.

Moritz, M.A., Morais, M.E., Summerell, L.A., Carlson, J.M., Doyle, J., 2005. Wildfires, complexity, and highly optimized tolerance. PNAS 102, 17912-17917.

Münster-Swendsen, M., 1984. The effect of precipitation on radial increment in Norway spruce (Picea abies Karst.) and on the dynamics of a lepidopteran pest insect. J. Appl. Ecol. 24, 563-571.

Negrón, J., 1997. Estimating probabilities of infestation and extent of damage by the roundheaded pine beetle in ponderosa pine in the Sacramento Mountains, New Mexico. Can. J. For. Res. 27, 1936-1945.

Negrón, J., Anhold, J.A., Munson, A.S., 2001. Within-stand spatial distribution of tree mortality caused by the Douglas-fir beetle (Coleoptera: Scolytidae). Commun. Ecosyst. Ecol. 30, 215-224.

Negrón, J.F., 1998. Probability of infestation and extent of mortality associated with the Douglas-fir beetle in the Colorado Front Range. For. Ecol. Manage. 107, 71-85.

Negrón, J.F., Allen, K., Cook, B., Withrow Jr., J.R., 2008. Susceptibility of ponderosa pine, Pinus ponderosa (Dougl. Ex Laws.) to mountain pine beetle, Dendroctonus ponderosae Hopkins, attack in uneven-aged stands in the Black Hills of South Dakota and Wyoming USA. For. Ecol. Manage. 254, 327-334.

Negrón, J.F., McMillin, J.D., Anhold, J.A., Coulson, D., 2009. Bark beetle-caused mortality in a drought-affected ponderosa pine landscape in Arizona, USA. For. Ecol Manage. 257, 1353-1362.

Negrón, J.F., Popp, J.B., 2004. Probability of ponderosa pine infestation by mountain pine beetle in the Colorado Front Range. For. Ecol. Manage. 191, 17-27.

Nepstadt, D., Lefebvre, P., Lopes da Silva, U., Tomasella, J., Schlesinger, P., Solórzano L., Moutinho, D.R., Benito, J.G., 2004. Amazon drought and its implications for forest flammability and tree growth: a basin-wide analysis. Glob. Change Biol. $10,704-717$.

Netherer, S., Nopp-Mayr, U., 2005. Predisposition assessment systems (PAS) as supportive tools in forest management-rating of site and stand-related hazards of bark beetle infestation in the High Tatra Mountains as an example for system application and verification. For. Ecol. Manage. 207, 99-107.

Netherer, S., Pennerstorfer, J., 2001. Parameters relevant for modelling the potential development of Ips typographus (Coleoptera: Scolytidae). Integr. Pest Manage. Rev. 6, 177-184.

Netherer, S., Schopf, A., 2010. Potential effects of climate change on insect herbivores in European forests-general aspects and the pine processionary moth as specific example. For. Ecol. Manage. 259, 831-838.

Ni, J., Harrison, S.P., Prentice, I.C., Kutzbach, J.E., Sitch, S., 2006. Impact of climate variability on present and Holocene vegetation: a model-based study. Ecol. Model. 191, 469-486.

Nicoll, B.C., Achim, A., Mochan, S., Gardiner, B.A., 2005. Does steep terrain influence tree stability? A field investigation. Can. J. For. Res. 35, 2360-2367.

Noble, I.R., Slatyer, R.O., 1977. Post-fire succession of plants in Mediterranean ecosystems. In: Symposium on Environmental Consequences of Fire and Fuel Management in Mediterranean Ecosystems, Palo Alto, CA, USA, pp. 27-36.

Noss, R.F., Franklin, J.F., Baker, W.L., Schoennagel, T., Moyle, P.B., 2006. Managing fire-prone forests in the western United States. Front. Ecol. Environ. 4 481-487.

Ogris, N., Jurc, M., 2010. Sanitary felling of Norway spruce due to spruce bark beetles in Slovenia: a model and projections for various climate change scenarios. Ecol. Model. 221, 290-302.

Økland, B., Berryman, A., 2004. Resource dynamic plays a key role in regional fluctuations of the spruce bark beetles Ips typographus. Agric. For. Entomol. 6, 141-146.

Økland, B., Bjørnstad, O.N., 2006. A resource-depletion model of forest insect outbreaks. Ecology 87, 283-290.

Økland, B., Liebhold, A.M., Bjørnstad, O.N., Erbilgin, N., Krokene, P., 2005. Are bark beetle outbreaks less synchronous than forest Lepidoptera outbreaks? Oecologia $146,365-372$.

Oliver, C.D., Larson, B.C. 1996. Forest Stand Dynamics. Wiley, New York, 520 pp.

Page, W.G., Jenkins, M.J., 2007. Mountain pine beetle-induced changes to selected lodgepole pine fuel complexes within the Intermountain Region. For. Sci. 53, 507-518.

Palik, B.J., Mitchell, R.J., Hiers, J.K., 2002. Modelling silviculture after natural disturbance to sustain biodiversity in the longleaf pine (Pinus palustris) ecosystem: balancing complexity and implementation. For. Ecol. Manage. 155, 347-356.

Panferov, O., Sogachev, A., 2008. Influence of gap size on wind damage variables in a forest. Agric. For. Met. 148, 1869-1881.

Papaik, M.J., Canham, C.D., 2006. Species resistance and community response to wind disturbance regimes in northern temperate forests. J. Ecol. 94, 1011-1026.

Papaik, M.J., Canham, C.D., Latty, E.F., Woods, K.D., 2005. Effects of an introduced pathogen on resistance to natural disturbance: beech bark disease and windthrow. Can. J. For. Res. 35, 1832-1843.

Parisien, M.-A., Moritz, M.A., 2009. Environmental controls on the distribution of wildfire at multiple spatial scales. Ecol. Monogr. 79, 127-154.

Park, Y., Chung, Y., 2006. Hazard rating of pine trees from a forest insect pest using artificial neural networks. For. Ecol. Manage. 222, 222-233.

Peltola, H., Kellomäki, S., Väisänen, H., Ikonen, V.P., 1999a. A mechanistic model for assessing the risk of wind and snow damage to single trees and stands of scots pine, Norway spruce, and birch. Can. J. For. Res. 29, 647-661.
Peltola, H., Kellomäki, S., Väisänen, H., 1999b. Model computations of the impact of climatic change on the windthrow risk of trees. Clim. Change 41, 17-36.

Peltonen, M., 1999. Windthrows and dead-standing trees as bark beetle breeding material at forest-clearcut edge. Scand. J. For. Res. 14, 505-511.

Peltonen, M., Liebhold, A.M., Bjørnstad, O.N., Williams, D.W., 2002. Spatial synchrony in forest insect outbreaks: roles of regional stochasticity and dispersal. Ecology 83, 3120-3129.

Perkins, D.L., Roberts, D.W., 2003. Predictive models of whitebark pine mortality from mountain pine beetle. For. Ecol. Manage. 174, 495-510.

Peterson, C.J., 2004. Within-stand variation in windthrow in southern boreal forests of Minnesota: is it predictable? Can. J. For. Res. 34, 365-375.

Peterson, D.L., Ryan, K.C., 1986. Modelling post-fire conifer mortality for long range planning. Environ. Manage. 10, 797-808.

Pitt, J.P.W., Régnière, J., Worner, S., 2007. Risk assessment of the gypsy moth, Lymantria dispar (L.), in New Zealand based on phenology modelling. Int. J. Biomet. 51, 295-305.

Pothier, D., Mailly, D., 2007. Stand-level prediction of balsam fir mortality in relation to spruce budworm defoliation. Can. J. For. Res. 36, 1631-1640.

Pothier, D., Mailly, D., Tremblay, S., 2005. Predicting balsam fir growth reduction caused by spruce budworm using large-scale historical records of defoliation. Ann. For. Sci. 62, 261-267.

Powell, J.A., Logan, J.A., 2005. Insect seasonality: circle map analysis of temperaturedriven life cycles. Theor. Popul. Biol. 67, 161-179.

Powers, J.S., Sollins, P., Harmon, M.E., Jones, J.A., 1999. Plant-pest interactions in time and space: a Douglas-fir bark beetle outbreak as a case study. Landsc. Ecol. 14, 105-120.

Prentice, I.C., Sykes, M.T., Cramer, W., 1993. A simulation model for the transient effects of climate change on forest landscapes. Ecol. Model. 65, 51-70.

Prestemon, J.P., Holmes, T.P., 2004. Market dynamics and optimal timber salvage after a natural catastrophe. For. Sci. 50, 495-511.

Pretzsch, H., Grote, R., Reineking, B., Rötzer, T., Seifert, S., 2008. Models for fores ecosystem management: a European perspective. Ann. Bot. 101, 1065-1087.

Price, P.W., 1991. The plant vigor hypothesis and herbivore attack. Oikos 62, 244-251.

Puettmann, K.J., Coates, K.D., Messier, C., 2009. A Critique of Silviculture. Managing for Complexity. Island Press, Washington, DC, 206 pp.

Quine, C.P., White, I.M.S., 1994. Using the relationship between rate of tatter and topographic variables to predict site windiness in upland Britain. Forestry 67 245-256.

Rademacher, C., Neuert, C., Grundmann, V., Wissel, C., Grimm, V., 2004. Reconstructing spatiotemporal dynamics of Central European natural beech forests: the rule-based forest model BEFORE. For. Ecol. Manage. 194, 349-368.

Raffa, K.F., Aukema, B.H., Bentz, B.J., Carroll, A.L., Hicke, J.A., Turner, M.G., Romme W.H., 2008. Cross-scale drivers of natural disturbances prone to anthropogenic amplification: the dynamics of bark beetle eruptions. BioScience 58, 501-517.

Railsback, S.F., 2001. Concepts from complex adaptive systems as a framework for individual-based modelling. Ecol. Model. 139, 47-62.

Rammig, A., Fahse, L., 2009. Simulating forest succession after blowdown events: the crucial role of space for a realistic management. Ecol. Model. 220, 3555-3564.

Rammig, A., Fahse, L., Bebi, P., Bugmann, H., 2007. Wind disturbance in mountain forests: simulating the impact of management strategies, seed supply, and ungulate browsing on forest succession. For. Ecol. Manage. 242, 142-154.

Rebetez, M., Mayer, H., Dupont, O., Schindler, D., Gartner, K., Kropp, J.P., Menzel, A., 2006. Heat and drought 2003 in Europe: a climate synthesis. Ann. For. Sci. 63 , 569-577.

Régnière, J., Bentz, B., 2007. Modelling cold tolerance in the mountain pine beetle, Dendroctonus ponderosae. J. Insect Phys. 53, 559-572.

Reich, R.M., Lundquist, J.E., Bravo, V.A., 2004. Spatial models for estimating fuel loads in the Black Hills, South Dakota, USA. Int. J. Wildland Fire 13, 119-129.

Reimoser, S., Partl, E., Reimoser, F., Vospernikc, S., 2009. Roe-deer habitat suitability and predisposition of forest to browsing damage in its dependence on forest growth: model sensitivity in an alpine forest region. Ecol. Model. 220, 2231-2243.

Reynolds, K.M., Holsten, E.H., 1996. Classification of spruce beetle hazard in Lutz and Sitka spruce stands on the Kenai Peninsula, Alaska. For. Ecol. Manage. 84, 251-262.

Rich, R.L., Frelich, L.E., Reich, P.B., 2007. Wind-throw mortality in the southern boreal forest: effects of species, diameter and stand age. J. Ecol. 95, 1261-1273.

Richards, G.D., 1999. The mathematical modelling and computer simulation of wildland fire perimeter growth over a 3-dimensional surface. Int. J. Wildland Fire 9, 213-221.

Richards, G.D., Bryce, R.W., 1995. A computer algorithm for simulating the spread of wildland fire perimeters for heterogeneous fuel and meteorological conditions. Int. J. Wildland Fire 5, 73-79.

Rigolot, E., 2004. Predicting postfire mortality of Pinus halepensis Mill. and Pinus pinea L. Plant Ecol. 171, 139-151.

Rodrigo, A., Retana, J., Pico, F.X., 2004. Direct regeneration is not the only response of Mediterranean forests to large fires. Ecology 85, 716-729.

Rollins, M.G., Keane, R.E., Parsons, R.A., 2004. Mapping fuels and fire regimes using remote sensing, ecosystem simulation, and gradient modelling. Ecol. Appl. 14 75-95.

Romero-Calcerrada, R., Novillo, C.J., Millington, J.D.A., Gomez-Jimenez, I., 2008. GIS analysis of spatial patterns of human-caused wildfire ignition risk in the SW o Madrid (Central Spain). Landsc. Ecol. 23, 341-354.

Rorig, M.L., Ferguson, S.A., 1999. Characteristics of lightning and wildland fire ignition in the Pacific Northwest. J. Appl. Met. 38, 1565-1575. 
Rothermel, R.C. 1972. A Mathematical Model for Predicting Fire Spread in Wildland Fuels. Rep. No. RP INT-115. SDA Forest Service, Ogden, UT.

Ruel, J.-C., Pin, D., Spacek, L., Cooper, K., Benoit, R., 1997. The estimation of wind exposure for windthrow hazard rating: comparison between Strongblow, MC2, Topex and a wind tunnel study. Forestry 70, 253-266.

Running, S.W., Coughlan, J.C., 1988. A general model of forest ecosystem processes for regional applications. I. Hydrologic balance, canopy gas exchange and primary production processes. Ecol. Model. 42, 125-154.

Ryan, K.C., Reinhardt, E.D., 1988. Predicting postfire mortality of seven western conifers. Can. J. For. Res. 18, 1291-1297.

Ryan, K.C., 2002. Dynamic interactions between forest structure and fire behavior in boreal ecosystems. Silva Fenn. 36, 13-39.

Sabate, S., Gracia, C.A., Sanchez, A., 2002. Likely effects of climate change on growth of Quercus ilex, Pinus halepensis, Pinus pinaster, Pinus sylvestris and Fagus sylvatica forests in the Mediterranean region. For. Ecol. Manage. 162, 23-37.

Schelhaas, M.J., 2008. The wind stability of different silvicultural systems for Douglas-fir in The Netherlands: a model-based approach. Forestry 81, 399-414.

Schelhaas, M.J., Kramer, K., Peltola, H., van der Werf, D.C., Wijdeven, S.M.J., 2007. Introducing tree interactions in wind damage simulation. Ecol. Model. 207, 197-209.

Schelhaas, M.J., Nabuurs, G.-J., Schuck, A., 2003. Natural disturbances in the European forests in the 19th and 20th centuries. Glob. Change Biol. 9, 1620-1633.

Schelhaas, M.J., Nabuurs, G.J., Sonntag, M., Pussinen, A., 2002. Adding natural disturbances to a large-scale forest scenario model and a case study for Switzerland. For. Ecol. Manage. 167, 13-26.

Scheller, R.M., Domingo, J.B., Sturtevant, B.R., Williams, J.S., Rudy, A., Gustafson, E.J., Mladenoff, D.J., 2007. Design, development, and application of LANDIS-II, a spatial landscape simulation model with flexible temporal and spatial resolution. Ecol. Model. 201, 409-419.

Scheller, R.M., Mladenoff, D.J., 2005. A spatially interactive simulation of climate change, harvesting, wind, and tree species migration and projected changes to forest composition and biomass in northern Wisconsin, USA. Glob. Change Biol. $11,307-321$.

Schindler, D., Grebhan, K., Albrecht, A., Schönborn, J., 2009. Modelling the wind damage probability in forests in Southwestern Germany for the 1999 winter storm 'Lothar'. Int. J. Biometeorol. 53, 543-554.

Schütz, J.P., Götz, M., Schmid, W., Mandallaz, D., 2006. Vulnerability of spruce (Picea abies) and beech (Fagus sylvatica) forest stands to storms and consequences for silviculture. Eur. J. For. Res. 125, 291-302.

Schumacher, S., Bugmann, H., 2006. The relative importance of climatic effects, wildfires and management for future forest landscape dynamics in the Swiss Alps. Glob. Change Biol. 12, 1435-1450.

Schumacher, S., Bugmann, H., Mladenoff, D.J., 2004. Improving the formulation of tree growth and succession in a spatially explicit landscape model. Ecol. Model. $180,175-194$.

Schumacher, S., Reineking, B., Sibold, J., Bugmann, H., 2006. Modelling the impact of climate and vegetation on fire regimes in mountain landscapes. Landsc. Ecol. $21,539-554$

Schwilk, D.W., Knapp, E.E., Ferrenberg, S.M., Keeley, J.E., Caprio, A.C., 2006. Tree mortality from fire and bark beetles following early and late season prescribed fires in a Sierra Nevada mixed - conifer forest. For. Ecol. Manage. 232, 36-45.

Scott, R.E., Mitchell, S.J., 2005. Empirical modelling of windthrow risk in partially harvested stands using tree, neighbourhood, and stand attributes. For. Ecol. Manage. 218, 193-209.

Seagle, S.W., Liang, S.Y., 2001. Application of a forest gap model for prediction of browsing effects on riparian forest succession. Ecol. Model. 144, 213-229.

Seely, B., Nelson, J., Wells, R., Peter, B., Meitner, M., Anderson, A., Harshaw, H., Sheppard, S., Bunnell, F.L., Kimmins, H., Harrison, D., 2004. The application of a hierarchical, decision-support system to evaluate multi-objective forest management strategies: a case study in northeastern British Columbia, Canada. For. Ecol. Manage. 199, 283-305.

Seidl, R., Baier, P., Rammer, W., Schopf, A., Lexer, M.J., 2007. Modelling tree mortality by bark beetle infestation in Norway spruce forests. Ecol. Model. 206, 383-399.

Seidl, R., Rammer, W., Jäger, D., Lexer, M.J., 2008. Impact of bark beetle (Ips typographus L.) disturbance on timber production and carbon sequestration in different management strategies under climate change. For. Ecol. Manage. 256, 209-220.

Seidl, R., Rammer, W., Lexer, M.J., in press. Climate change vulnerability of sustainable forest management in the Eastern Alps. Clim. Change.

Seidl, R., Schelhaas, M.J., Lindner, M., Lexer, M.J., 2009. Modelling bark beetle disturbances in a large scale forest scenario model to assess climate change impacts and evaluate adaptive management strategies. Reg. Environ. Chang. 9, 101-119.

Shifley, S.R., Thompson III, F.R., Dijak, W.D., Larson, M.A., Millspaugh, J.J., 2006. Simulated effects of forest management alternatives on landscape structure and habitat suitability in the Midwestern United States. For. Ecol. Manage. 229, 361-377.

Shore, T.L., Safranyik, L., Riel, W., Ferguson, M., Castonguay, J., 1999. Evaluation of factors affecting tree and stand susceptibility to the Douglas-fir beetle (Col., Scol.). Can. Entomologist 131, 831-839.

Sieg, C.H., McMillin, J.D., Fowler, J.F., Allen, K.K., Negron, J.F., Wadleigh, L.L., Anhold, J.A., Gibson, K.E., 2006. Best predictors for postfire mortality of Ponderosa pine trees in the Intermountain West. For. Sci. 52, 718-728.

Sitch, S., Smith, B., Prentice, I.C., Arneth, A., Bondeau, A., Cramer, W., Kaplan, J.O., Levis, S., Lucht, W., Sykes, M.T., Thonicke, K., Venevsky, S., 2003. Evaluation of ecosystem dynamics, plant geography and terrestrial carbon cycling in the LPJ dynamic global vegetation model. Glob. Change Biol. 9, 161-185.
Smith, E.L., McMahan, A.J. David, L. Beukema, S.J. Robinson, D.C., 2005. Westwide Pine Beetle Model Version 2.0: Detailed Description. FHTET 05-06. U.S. Department of Agriculture, Forest Service, Forest Health Protection, Forest Health Technology Enterprise Team, Fort Collins, CO, 101 pp.

Solberg, S., 2004. Summer drought: a driver for crown condition and mortality of Norway spruce in Norway. For. Pathol. 34, 93-104.

Speight, M., Wainhouse, D., 1989. Ecology and Management of Forest Insects. Clarendon Press, Oxford.

Spies, T.A., 2009. Science of old growth, or a journey into wonderland. In: Spies, T.A., Duncan, S.L. (Eds.), Old Growth in a New World: A Pacific Northwest Icon Reexamined. Island Press, Washington, DC, pp. 31-43.

Steinbauer, M.J., Kriticos, D.J., Lukacs, Z., Clarke, A.R., 2004. Modelling a forest lepidopteran: phenological plasticity determines voltinism which influences population dynamics. For. Ecol. Manage. 198, 117-131.

Stocks, B.J., 1987. Fire potential in the spruce budworm-damaged forests of Ontario. For. Chron. 63, 8-14.

Strand, E.K., Vierling, L.A., Bunting, S.C., Gessler, P.E., 2009. Quantifying successional rates in western aspen woodlands: current conditions, future predictions. For. Ecol. Manage. 257, 1705-1715.

Sturtevant, B.R., Gustafson, E.J., Li, W., He, H.S., 2004. Modelling biological disturbances in LANDIS: a module description and demonstration using spruce budworm. Ecol. Model. 180, 153-174.

Suarez, J., Gardiner, B.A., Quine, C.P., 1999. A comparison of three methods for predicting wind speeds in complex forested terrain. Meteorol. Appl. 6, $329-342$.

Sullivan, A., 2009. Wildland surface fire spread modelling, 1990-2007. 3: simulation and mathematical analogue models. Int. J. Wildland Fire 18, 387-403.

Sutherst, R.W., Maywald, G.F., 1985. A computerized system for matching climates in ecology. Agric. Ecosyst. Environ. 13, 281-299.

Sutherst, R.W., Maywald, G.F., Russell, B.L., 2000. Estimating vulnerability under global change: modular modelling of pests. Agric. Ecosyst. Environ. 82, 303-319.

Swanson, F.J., Chapin III, F.S., 2009. Forest systems: living with long-term change. In: Chapin III, F.S., Kofinas, G.P., Folke, C.(Eds.), Principles of Ecosystem Stewardship. Resilience-based Natural Resource Management in a Changing World. Springer, New York, pp. 149-170.

Syphard, A.D., Radeloff, V.C., Keuler, N.S., Taylor, R.S., Hawbaker, T.J., Stewart, S.I., Clayton, M.K., 2008. Predicting spatial patterns of fire on a southern California landscape. Int. J. Wildland Fire 17, 602-613.

Tague, C.L., Band, L.E., 2001. Evaluating explicit and implicit routing for watershed hydro-ecological models of forest hydrology at the small catchment scale. Hydrol. Process. 15, 1415-1439.

Talkkari, A., Peltola, H., Kellomaki, S., Strandman, H., 2000. Integration of component models from the tree, stand and regional levels to assess the risk of wind damage at forest margins. For. Ecol. Manage. 135, 303-313.

Tang, S.M., Franklin, J.F., Montgomery, D.R., 1997. Forest harvest patterns and landscape disturbance processes. Landsc. Ecol. 12, 349-363.

Tester, J.R., Starfield, A.M., Frelich, L.E., 1997. Modelling for ecosystem management in Minnesota pine forests. Biol. Conserv. 80, 313-324.

Thompson, J.R., Spies, T.A., 2009. Vegetation and weather explain variation in crown damage within a large mixed-severity wildfire. For. Ecol. Manage. 258, 1684-1694.

Thonicke, K., Cramer, W., 2006. Long-term trends in vegetation dynamics and forest fires in Brandenburg (Germany) under a changing climate. Nat. Hazards 38 , 283-300.

Thornton, P.E., Law, B.E., Gholz, H.L., Clark, K.L., Falge, E., Ellsworth, D.S., Goldstein, A.H., Monson, R.K., Hollinger, D., Falk, M., Chen, J., Sparks, J.P., 2002. Modelling and measuring the effects of disturbance history and climate on carbon and water budgets in evergreen needleleaf forests. Agric. For. Met. 113, 185-222.

Thürig, E., Palosuo, Bucher, J., Kaufmann, E., 2005. The impact of windthrow on carbon sequestration in Switzerland: a model-based assessment. For. Ecol. Manage. 210, 337-350.

Tiktak, A., van Grinsven, H.J.M., 1995. Review of sixteen forest-soil-atmosphere models. Ecol. Model. 83, 35-53.

Tobin, P.C., Nagarkatti, S., Loeb, G., Saunders, M.C., 2008. Historical and projected interactions between climate change and insect voltinism in a multivoltine species. Glob. Change Biol. 14, 951-957.

Turner, M.G., 2005. Landscape ecology: What is the state of the science? Ann. Rev. Ecol. Evol. Syst. 36, 319-344.

Ungerer, M.J., Ayres, M.P., Lombardero, M.J., 1999. Climate and the northern distribution limits of Dendroctonus frontalis Zimmermann (Coleoptera: Scolytidae). J. Biogeogr. 26, 1133-1145.

Urban, D.L., Acevedo, M.F., Garman, S.L., 1999. Scaling fine-scale processes to large-scale patterns using models derived from models: meta-models. In: Mladenoff, D.J., Baker, W.L. (Eds.), Spatial Modelling of Forest Landscape Change: Approaches and Applications. Cambridge University Press, Cambridge, pp. 70-98.

Uriarte, M., Papaik, M., 2007. Hurricane impacts on dynamics, structure and carbon sequestration potential of forest ecosystems in Southern New England, USA. Tellus 59A, 519-528.

Valinger, E., Fridman, J., 1999. Models to assess the risk of snow and wind damage in pine, spruce, and birch forests in Sweden. Environ. Manage. 24, 209-217.

van Asch, M., Tienderen, P.H., Holleman, L.J.M., Visser, M.E., 2007. Predicting adaptation of phenology in response to climate change, an insect herbivore example. Glob. Change Biol. 13, 1596-1604.

van Mantgem, P.J., Stephenson, N.L., Byrne, J.C., Daniels, L.D., Franklin, J.F., Fulé, P.Z., Harmon, M.E., Larson, A.J., Smith, J.M., Taylor, A.H., Veblen, T.T., 2009. 
Widespread increase of tree mortality rates in the Western United States. Science $323,521-524$.

van Minnen, J.G., Meijers, R., Braat, L.C., 1995. Application of the FORSOL model to the spruce site at Solling, Germany. Ecol. Model. 83, 197-205.

van Wagner, C.E., 1977. Conditions for the start and spread of crown fire. Can. J. For. Res. 7, 23-34.

van Wagner, C.E., 1973. Height of crown scorch in forest fires. Can. J. For. Res. 3, 373-378.

van Wagner, C.E., Pickett, T.L., 1985. Equations and FORTRAN Program for the Canadian Forest Fire Weather Index System. Rep. No. Forestry Technical Report 33. Canadian Forestry Service, Ottawa.

Vanhanen, H., Veleli, T.O., Päivinen, S., Kellomäki, S., Niemelä, P., 2007. Climate change and range shifts in two insect defoliators: Gypsy moth and nun moth-a model study. Silva Fenn. 41, 621-638.

Varner, J.M., Hiers, J.K., Ottmar, R.D., Gordon, D.R., Putz, F.E., Wade, D.D., 2007. Overstory tree mortality resulting from reintroducing fire to long-unburned longleaf pine forests: the importance of duff moisture. Can. J. For. Res. 37, 1349-1358.

Vázquez, A., Moreno, J.M., 2001. Spatial distribution of forest fires in Sierra de Gredos (Central Spain). For. Ecol. Manage. 147, 55-65.

Vega-García, C., Chuvieco, E., 2006. Applying local measures of spatial heterogeneity to Landsat-TM images for predicting wildfire occurrence in Mediterranean landscapes. Landsc. Ecol. 21, 595-605.

Venäläinen, A., Zeng, H., Peltola, H., Talkkari, A., Strandman, H., Wang, K., Kellomäki, S., 2004. Simulations of the influence of forest management on wind climate on a regional scale. Agric. For. Met. 123, 149-158.

Venevsky, S., Thonicke, K., Sitch, S., Cramer, W., 2002. Simulating fire regimes in human-dominated ecosystems: Iberian Peninsula case study. Glob. Change Biol. 8, 984-998.

Vera, F.W.M., 2000. Grazing Ecology and Forest History. CABI Publishing, Wallingford, $528 \mathrm{pp}$.

Veteli, T.O., Koricheva, J., Niemelä, P., Kellomäki, S., 2006. Effects of forest management on the abundance of insect pests on Scots pine. For. Ecol. Manage. 231, 214-217.

Viedma, O., Angeler, D.G., Moreno, J.M., 2009. Landscape structural features control fire size in a Mediterranean forested area of central Spain. Int. J. Wildland Fire $18,575-583$.

Vospernik, S., Reimoser, S., 2008. Modelling changes in roe deer habitat in response to forest management. For. Ecol. Manage. 255, 530-545.

Waring, R.H., Pitman, G.B., 1983. Physiological stress in lodgepole pine as a precursor for mountain pine-beetle attack. J. Appl. Entomol. 96, 265-270.

Weber, P., Rigling, A., Bugmann, H., 2008. Sensitivity of stand dynamics to grazing in mixed Pinus sylvestris and Quercus pubescens forests: a modelling study. Ecol. Model. 210, 301-311.

Wehrli, A., Weisberg, P.J., Schoenenberger, W., Brang, P., Bugmann, H., 2007. Improving the establishment submodel of a forest patch model to assess the long-term protective effect of mountain forests. Eur. J. For. Res. 126, 131-145.

Weibel, P., 2009. Modelling and assessing fire regimes in mountain forests of Switzerland. Ph.D. Thesis No. 18699. Swiss Federal Institute of Technology Zurich, 144.

Weibel, P., Reineking, B., Conedera, M., Bugmann, H., 2010. Environmental determinants of lightning- vs. human-induced forest fire ignitions differ in a temperate mountain region of Switzerland. Int. J. Wildland Fire 19, 541-557.

Weisberg, P.J., Bonavia, F., Bugmann, H., 2005. Modelling the interacting effects of browsing and shading on mountain forest tree regeneration (Picea abies). Ecol Model. 185, 213-230.

Weisberg, P.J., Bugmann, H., 2003. Forest dynamics and ungulate herbivory: from leaf to landscape. For. Ecol. Manage. 181, 1-12.

Weisberg, P.J., Coughenour, M.B., Bugmann, H., 2006. Integration of large herbivorevegetation processes in a landscape context. In: Danell, K., Bergström, R., Duncan, P., Pastor, J., Olff, H. (Eds.), Large Herbivore Ecology and Ecosystem Dynamics. Cambridge University Press, Cambridge, pp. 348-382.

Wermelinger, B., Seifert, M., 1998. Analysis of the temperature dependent development of the spruce bark beetle Ips typographus (L.) (Col, Scolytidae). J. Appl Entomol. 122, 185-191.
Westerling, A.L., Hidalgo, H.G., Cayan, D.R., Swetnam, T.W., 2006. Warming and earlier spring increase western U.S. forest wildfire activity. Science 313, 940-943.

White, J.D., Gutzwiller, K.J., Barrow, W.C., Randall, L.J., Swint, P., 2008. Modeling mechanisms of vegetation change due to fire in a semi-arid ecosystem. Ecol. Model. 214, 181-200.

White, P.S., Jentsch, A., 2001. The search for generality in studies of disturbance and ecosystem dynamics. Prog. Bot. 62, 399-449.

White, P.S., Pickett, S.T.A., 1985. Natural disturbances and patch dynamics: an introduction. In: White, P.S., Pickett, S.T.A. (Eds.), The Ecology of Natural Disturbances and Patch Dynamics. Academic Press, San Diego, pp. 1-15.

White, T.C.R., 2009. Plant vigour versus plant stress: a false dichotomy. Oikos 118, 807-808.

Wigmosta, M.S., Vail, L.W., Lettenmaier, D.P., 1994. A distributed hydrologyvegetation model for complex terrain. Water Resour. Res. 30, 1665-1679.

Wilder, J.W., 1999. A predictive model for gypsy moth population dynamics with model validation. Ecol. Model. 116, 165-181.

Wilson, J., 2004. Vulnerability to wind damage in managed landscapes of the coastal Pacific Northwest. For. Ecol. Manage. 191, 341-351.

Wisdom, M.J., Vavra, M., Boyd, J.M., Hemstrom, M.A., Ager, A.A., Johnson, B.K. 2006. Understanding ungulate herbivory-episodic disturbance effects on vegetation dynamics: knowledge gaps and management needs. Wildlife Soc. Bull. 34, 283-292.

Wolf, A., Kozlov, M.V., Callaghan, T.V., 2008. Impact of non-outbreak insect damage on vegetation in northern Europe will be greater than expected during a changing climate. Clim. Change 87, 91-106.

Wolfslehner, B., Seidl, R., in press. Harnessing ecosystem models and multi-criteria decision analysis for the support of forest management. Environ. Manage.

Wong, C.M., Iverson, K., 2004. Range of natural variability: applying the concept to forest management in central British Columbia, BC. J. Ecosyst. Manage. Extension Note 4, 1-56.

Woodall, C.W., Nagel, L.M., 2007. Downed woody fuel loading dynamics of a largescale blowdown in northern Minnesota, U.S.A. For. Ecol. Manage. 247, 194-199.

Wotton, B.M., Martell, D.L., Logan, K.A., 2003. Climate change and people-caused forest fire occurrence in Ontario. Clim. Change 60, 275-295.

Wulder, M.A., White, J.C., Bentz, B., Alvarez, M.F., Coops, N.C., 2006. Estimating the probability of mountain pine beetle red-attack damage. Remote Sens. Environ. $101,150-166$.

Wullschleger, S.D., Jackson, R.B., Currie, W.S., Friend, A.D., Luo, Y., Mouillot, F., Pan, Y., Shao, G., 2001. Below-ground processes in gap models for simulating forest response to global change. Clim. Change 51, 449-473.

Wunder, J., Bigler, C., Reineking, B., Fahse, L., Bugmann, H., 2006. Optimisation of tree mortality models based on growth patterns. Ecol. Model. 197, 196-206.

Wunder, J., Brzeziecki, B., Żybura, H., Reineking, B., Bigler, C., Bugmann, H., 2008 Growth-mortality relationships as indicators of life-history strategies: a comparison of nine tree species in unmanaged European forests. Oikos 117, 815-828.

Youngblood, A., Grace, J.B., McIver, J.D., 2009. Delayed conifer mortality after fuel reduction treatments: interactive effects of fuel, fire intensity, and bark beetles. Ecol. Appl. 19, 321-337.

Zavala, M.A., Bravo de la Parra, R., 2005. A mechanistic model of tree competition and facilitation for Mediterranean forests: scaling from leaf physiology to stand dynamics. Ecol. Model. 188, 76-92.

Zeng, H., Peltola, H., Talkkari, A., Strandman, H., Venäläinen, A., Wang, K., Kellomäki, S., 2006. Simulations of the influence of clear-cutting on the risk of wind damage on a regional scale over a 20-year period. Can. J. For. Res. 36, 2247-2258.

Zeng, H., Peltola, H., Väisänen, H., Kellomäki, S., 2009. The effects of fragmentation on the susceptibility of a boreal forest ecosystem to wind damage. For. Ecol. Manage. 257, 1165-1173.

Zeng, H., Talkkari, A., Peltola, H., Kellomäki, S., 2007. A GIS-based decision support system for risk assessment of wind damage in forest management. Environ. Model. Software 22, 1240-1249.

Zhu, J., Rasmussen, J.G., Moller, J., Aukema, B.H., Raffa, K.F., 2008. Spatial-temporal modelling of forest gaps generated by colonization from below- and aboveground bark beetle species. J. Am. Stat. Assoc. 103, 162-177.

Zinck, R.D., Grimm, V., 2009. Unifying wildfire models from ecology and statistical physics. Am. Naturalist 174, E170-E185. 